\title{
BA- $0418-9$
}

\section{OPERATING COSTS AND PLANT OPTIONS ANALYSIS FOR THE SHAMOKIN FLUIDIZED BED BOILER}

\author{
By \\ M. G. Klett \\ T. E. Dowdy \\ R. Litman
}

March 1984

Work Performed Under Contract No.: DE-AM21-82MC19045

For

U. S. Department of Energy

Office of Fossil Energy

Morgantown Energy Technology Center

Morgantown, West Virginia

By

Gilbert Associates, Inc.

Reading, Pennsylvania 


\section{DISCLAIMER}

This report was prepared as an account of work sponsored by an agency of the United States Government. Neither the United States Government nor any agency Thereof, nor any of their employees, makes any warranty, express or implied, or assumes any legal liability or responsibility for the accuracy, completeness, or usefulness of any information, apparatus, product, or process disclosed, or represents that its use would not infringe privately owned rights. Reference herein to any specific commercial product, process, or service by trade name, trademark, manufacturer, or otherwise does not necessarily constitute or imply its endorsement, recommendation, or favoring by the United States Government or any agency thereof. The views and opinions of authors expressed herein do not necessarily state or reflect those of the United States Government or any agency thereof. 


\section{DISCLAIMER}

Portions of this document may be illegible in electronic image products. Images are produced from the best available original document. 


\title{
DISCLAIMER
}

\begin{abstract}
This report was prepared as an account of work sponsored by an agency of the United States Government. Neither the United States Government nor any agency thereof, nor any of their employees, makes any warranty, express or implied, or assumes any legal liability or responsibility for the accuracy, completeness, or usefulness of any information, apparatus, product, or process disclosed, or represents that its use would not infringe privately owned rights. Reference herein to any spccific commercial product, process, or service by trade name, trademark, manufacturer, or otherwise does not necessarily constitute or imply its endorsement, recommendation, or favoring by the United States Government or any agency thereof. The views and opinions of authors expressed herein do not necessarily state or reflect those of the United States Government or any agency thereof.
\end{abstract}

This report has been reproduced directly from the best available copy.

Available from the National Technical Information Service, U. S. Department of Commerce, Springfield, Virginia 22161.

Price: Printed Copy A05

Microfiche A01

Codes are used for pricing all publications. The code is determined by the number of pages in the publication. Information pertaining to the pricing codes can be found in the current issues of the fulluwing publications, which are generally available in most libraries Fnergy Research Abstracts (ERA); Government Reports Announcements and Index (GRA and I); Scientific and Technical Abstract Reports (STAR); and publication NTIS-PR-360 available from NTIS at the above address. 


\title{
OPERATING COSTS AND PLANT OPTIONS ANALYSIS FOR THE SHAMOKIN FLUIDIZED BED BOILER
}

\author{
By \\ M. G. Klett \\ T. E. Dowdy \\ R. Litman \\ March 1984 \\ Work Performed Under Contract No.: DE-AM21-82MC19045 \\ For \\ U. S. Departinent of Energy \\ Office of Fossil Energy \\ Morgantown Energy Technology Center \\ P. O. Box 880 \\ Morgantown, West Virginia 26505 \\ By \\ Gilhert. Associates, Inc. \\ Reading, Pennsylvania 19603
}




\section{THIS PAGE \\ WAS INTENTIONALLY \\ LEFT BLANK}

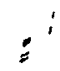

$1 \because$ 
TABLE OF CONTENTS

Section

Title

$\underline{\text { Page }}$

1.0

SUMMARY

1

2.0

INTRODUCTION

3.0

DATA COLLECTION AND ANALYSIS

4.0

4.1

OPERATING COST PROJECTIONS - HISTORICAL OPERATIONS

20

OPERATING COST ESTIMATE

20

4.2

COMPARISONS WITH PROJECTED COSTS AND REVENUES

5.0

5.1

OPERATING COST PROJECTIONS - FUTURE OPERATIONS

29

OPERATING COST ESTIMATE - PRESENT CONFIGURATION

29

5.2

5.3

SENSITIVITY ANALYSIS - PRESENT CONFIGURATION

33

OPERATING COST ESTIMATES - RECONFIGURED. PLANT .

42

5.4

5.5

SENSITIVITY ANALYSIS - RECONFIGURED PLANT

OPTIONS TO IMPROVE PLANT ECONOMICS

46

Increase Steam Sales and/or Price

5.5 .1

Replacement of Electric Drives with Steam Turbine Drives

49

49 .

52

Reducing or Eliminating Limestone Feed . 53

5.5 .3

5.5 .4

Operating Labor

54

6.0

CONCLUSIONS

57

7.0

REFERENCES

Appendix A Landfill Regulatory Requirements for Disposal of Ash

Appendix B Sample Calculations

Appendix C-1 Shamokin Operating Cost Summary $\quad 80$

Appendix C-2. Shamokin Operating Cost Summary Gross Sales Options 88

Appendix D Definition of Terms

92 


\section{TABLES}

\section{Table}

Page

1

2

3

4

5

Fluidized Bed Boiler Design Parameters

Shamokin Anthracite Culm-Fired Boiler

Operating Summary

Ultimate Analysis of Shamokin Anthracite Culm

Typical Limestone Analysis

Electric Power Coses

16

Watar Costs :

16

Other Variable Costs

Fixed Costs

Shamokin Anthracite Culm Boiler Extended Test

Plant Availability

Base Case Parameters - Historical

Historical Base Case - Cost Breakdown

Projected Operations and Maintenance Costs

Budgeted Versus Actual Cost - Extended Test Period

Basc Casc Paramctcrs - Full Commcrcial Opcration.

Commercial Operation Base Case - Cost Breakdown

Sensitivity Summaries - Commercial Operation

Reconfigured Plant Base Case - Cost Breakdown

Sensitivity Summaries - Reconfigured Plant

Steam Cost from Oil or Gas Fired Boiler

Effect of Operating Labor Requirement on Operating

56 Cost 
FIGURES

Figures

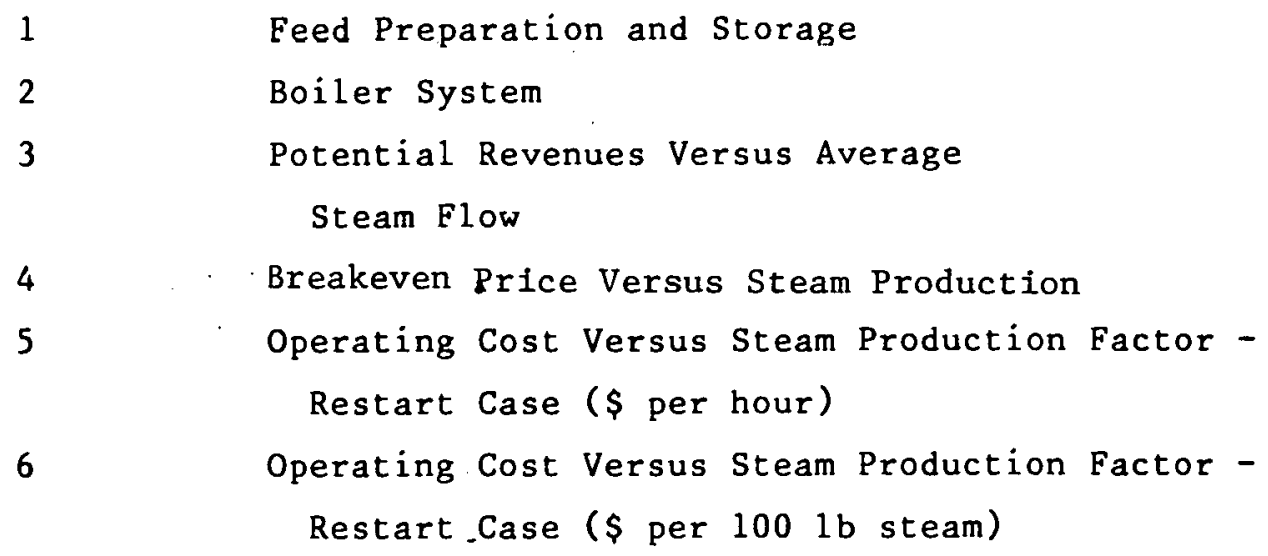

Restart Case ( $\$$ per hour)

Operating Cost Versus Steam Production Factor -

Restart Case ( $\$$ per $1001 \mathrm{~b}$ steam)

$\underline{\text { Page }}$

v 
This report presents the results of a study that examined the operating costs and options to improve the Shamokin Atmospheric Fluidized Bed Combustion Demonstration Plant located near Shamokin, Pennsylvania. The purpose of this study was to perform an operating cost analysis and compare the results with projected operating costs. An analysis was also made to identify possible cost savings options. Two base case scenarios were developed for this study:

- The first scenario assumed that the plant operated in a manner similar to operations during the extended test program.

- The second scenario was concerned with two options. One option assumed upgrading the plant to achieve continuous full load operation, restarting, and used revised costs and revenues. The second assumed reconfiguring the plant for cogeneration.

A sensitivity analysis was performed using parameters such as steam production factor (load factor times availability), anthracite culm cost, limestone cost, combustion efficiency, $\mathrm{Ca} / \mathrm{s}$ ratio, waste disposal costs, and operating labor requirements.

Based on the plant performance data, the operating cost estimates, and the cost sensitivity analysis, the following conclusions are made:

a The Shamokin facility has demonstrated the technical ability to generatc steam from anthracite culm with both a high reliability and reasonable operating cost. However, the current steam selling price is too low to recover full operating costs even at full steam flow. A steam selling price of approximately $\$ 6$ per $1000 \mathrm{lb}$ of steam would allow the unit 
to break-even on an operating and maintenance basis at steam sales rates of $11,5001 \mathrm{bs} / \mathrm{hr}$. This price should be very competitive if customers can be found.

b. Projected and actual operating costs show substantial agreement .

c. The largest contributors to operating costs are 1 abor and electricity which each make up about 30 percent of operating rnst.s. No other item makss up more than 10 pcrcent of operating costs.

d. None of the cogeneration options could allow operaliun at "break-even," much less pay back the relatively large investments required for cogeneration. Essentially, the boiler is too small in capacity and the design steam temperature and pressure is too low for the unit to be a cost effective power generator. No other system changes could be recommended which would reduce operating costs substantially. 
In the Fall of 1978, the U.S. Department of Energy awarded a contract to the Shamokin Area Industrial Corporation (SAIC) of Shamokin, Pennsylvania to design, construct, and operate a fluidized bed boiler fueled with anthracite culm, waste product from anthracite coal preparation. The project team supporting SAIC, an industrial- development oriented agency seeking to bring new jobs and industry to the Shamokin area, included Dorr Oliver and E. Keeler Company who, together, designed and built the fluidized bed boiler. Stone and Webster Engineering Corporation was responsible for the fuel preparation and water treatment systems as well as the overall plant integration. Curtiss-Wright Corporation was the overall program manager with management and procurement responsibilities, and was additionally responsible for the automatic control system and instrumentation.

The boiler plant was designed to produce $20,0001 \mathrm{~b} / \mathrm{hr}$ of $200-\mathrm{psig}$ saturated steam, to be sold to a nearby paper manufacturer or other customers on a variable-demand basis 24 hours a day, 7 days a week. Figures 1 and 2 show the demonstration plant equipment and flow diagram. Table 1 gives the design boiler data.

The plant began initial operation in August 1981. After startup and shakedown tests, 17 parametric tests were conducted between October 1981 and June 1982. Continuous plant operation resumed on August 9, 1982, after completion of the parametric testing and a scheduled annual maintenance period. The plant ran continuously from August 9, 1982 to April 30, 1983, when it was shut down due to completion of the DOE-supported program. Cellu Products Corporation, the only commercial customer for the steam, purchased an average of only $3000 \mathrm{lb} / \mathrm{hr}$ during this period. The plant, while operating continuously, was only at about 40 percent load. Excess steam above the $3000 \mathrm{lb} / \mathrm{hr}$ utilized by the customer (approximately $50001 \mathrm{~b} / \mathrm{hr}$ ) was vented to the atmosphere. 


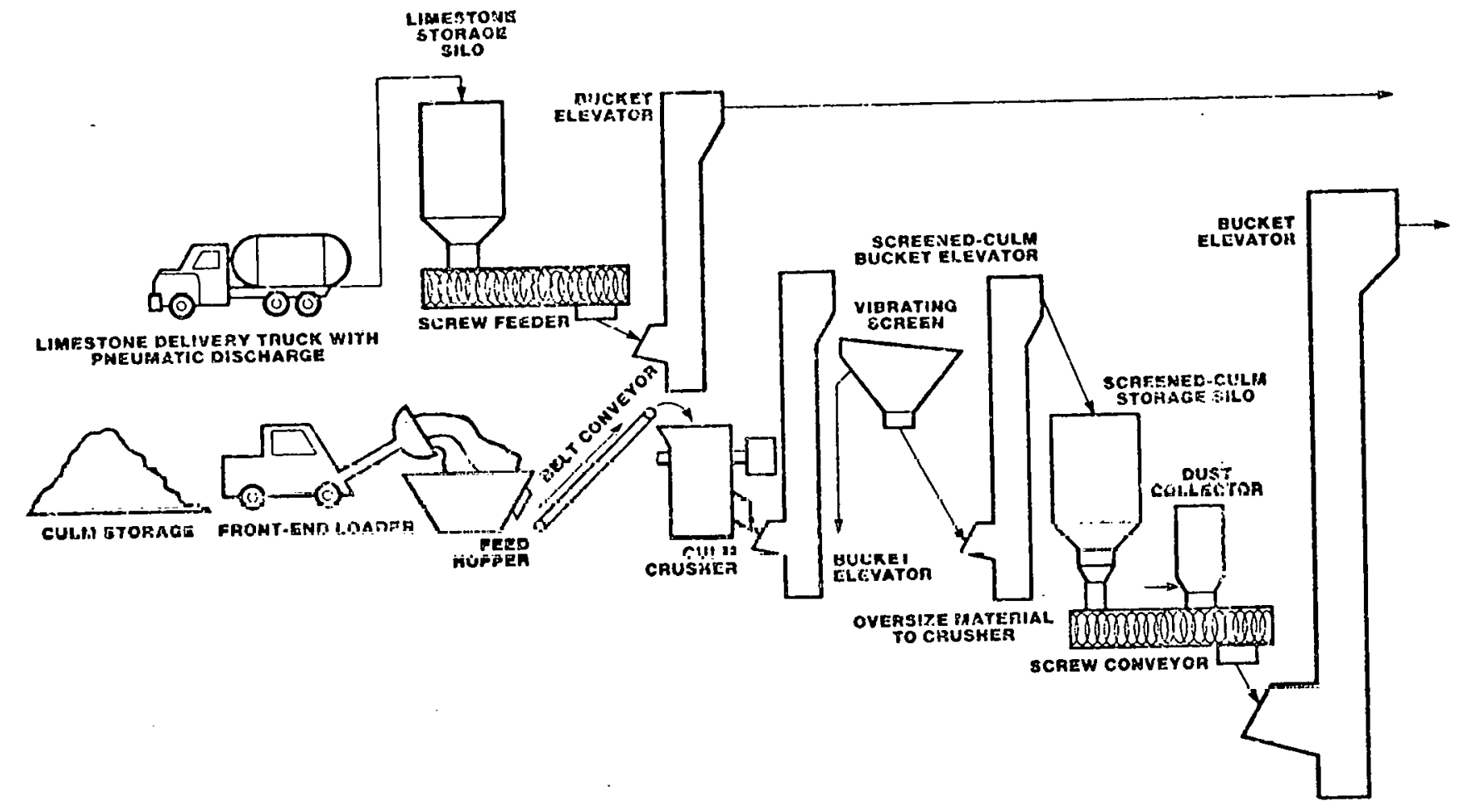

Figure 1

Feed Preparation and Storage

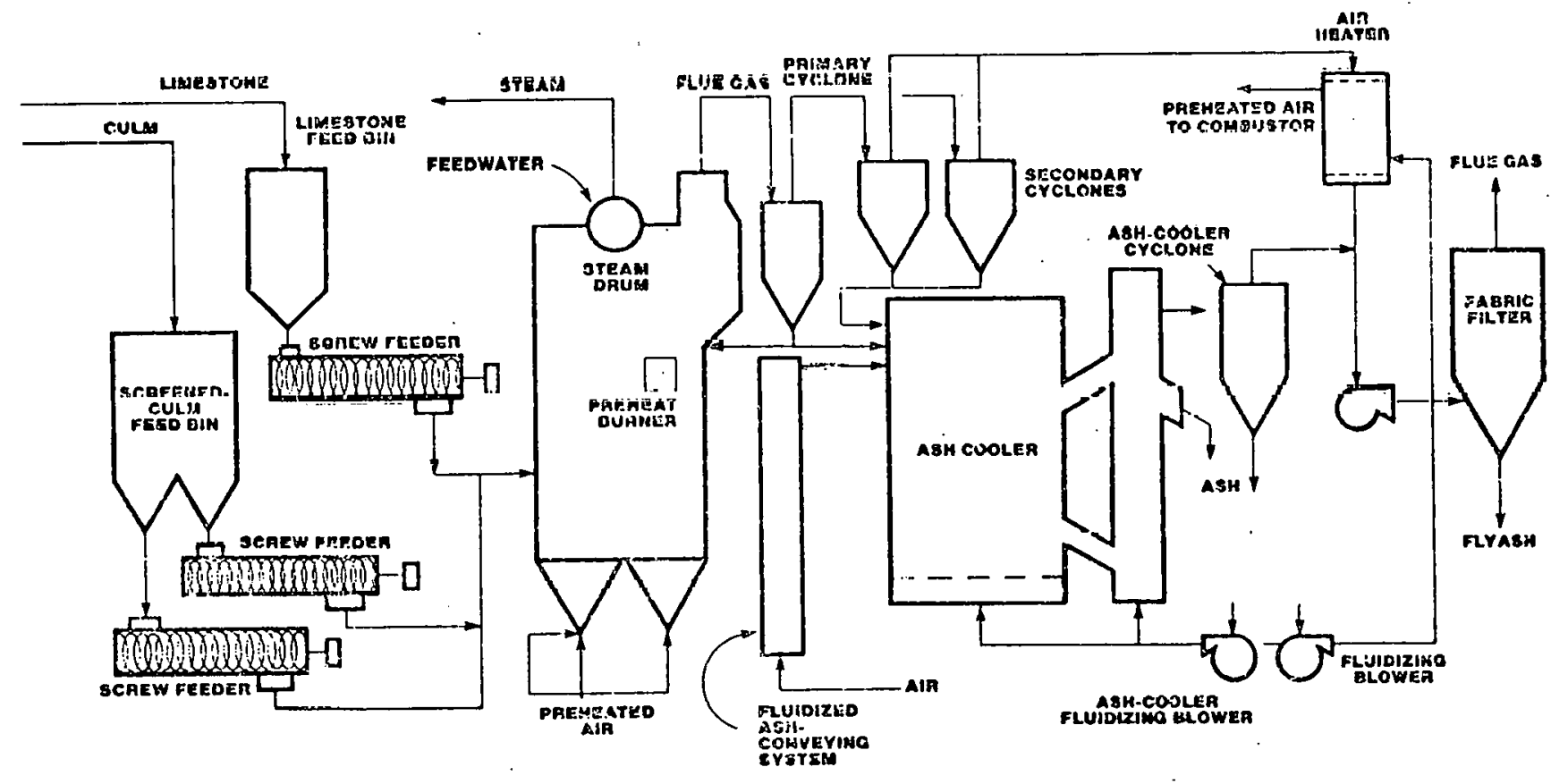

Figure 2

Bciler System 
TABLE 1

FLUIDIZED BED BOILER DESIGN PARAMETERS

Steam Flow, net

Steam Flow, gross*

Steam Condition

Bed Dimensions

Bed Height

Fluidizing velocity

Bed Temperature

Sulfur Capture

Turndown (steam)

Convection Area

Furnace Area

Freeboard Height

Furnace Volume

$* 34001 \mathrm{~b} / \mathrm{hr}$ used internally by deaerator
$20,0001 \mathrm{~b} / \mathrm{hr}$

$23,4001 \mathrm{~b} / \mathrm{hr}$

200 psig saturated

$10 \times 10 \mathrm{ft}$

$4-6 \mathrm{ft}$

$3.5-6 \mathrm{ft} / \mathrm{s}$

$1450-1650^{\circ} \mathrm{F}$

$88 \%$

$2.5-1$

$2966 \mathrm{ft}^{2}$

$1360 \mathrm{ft}^{2}$

$16 \mathrm{ft}$

$2100 \mathrm{ft}^{3}$ 
This study was conducted in two phases.

The objectives of the first phase were to:

- Document the historical operating costs, and, thereby, the steam production cost and revenue requirements (excluding capital charges) for the AFBC Demonstration Plant,

- Perform a sensitivity analysis to identify those parameters which have the greatest effect on the operating cost, and

- Define cost saving recommendations that might make future operation of the plant economically viable.

After a review of the first phase assumptions by SAIC and Curtiss-Wright, the second phase of the study began. The objectives of the second phase were to:

- Compare actual to projected cost and revenues.

- Based on operating cost saving recommendations of Phase I, assess the options that could reduce operating costs or increase revenues.

This report presents the results of both phases.

The study contains an estimate of the operating costs for the plant based primarily on historical operating and maintenance costs from the extended run period of August 9, 1982, to April 30, 1983. During this period of operation, culm was supplied free of charge, solid wastes were stored temporarily on-site, and steam was sold at an attractive price to the consumer. It was also found that, because of some minor bottlenecks, the plant could not operate 
continuously at full load. Thus, two base case scenarios were developed for this study:

- The first scenario assumed that the plant operated in a manner similar to operations during the extended test program, (i.e., the historical base case).

- The second scenario was concerned with two options. Option A assumed upgrading the plant to achieve full load continuously, restarting, and assuming revised costs and revenues (i.e., the full commercial operation base case). Option $B$ assumed reconfiguring the plant for cogeneration (i.e., the reconfigured plant base case).

A sensitivity analysis was performed using parameters such as steam production factor (load factor times availability), culm cost, limestone cost, combustion efficiency, Ca/S ratio, waste disposal costs, and operating labor requirements.

It should be noted that the operating costs established in this report are for a site specific first-of-a-kind demonstration plant. In general, these costs should not be used for generic fluidized bed boiler operating costs or for comparison with alternative methods and fuels for steam production. 
3.0 DATA COLLECTION AND ANALYSIS

Reliable consumption rates and unit costs for raw materials, utilities, waste disposal, and labor were required to estimate operating costs. Such data were obtained by discussions with Curtiss-Wright and Shamokin Area Industrial Corporation personnel as well as from published sources. Historical data from the nine month extended test were obtained from Curtiss-Wright and are summarized in Table 2 .

Euel Cost: The fuel used is anthracite culm. The shamokin area contains mountains of anthracite culm that have accumulated over the years. I'his culm presents an eye sore to the community as well as an environmental problem because of acid water runoff. Several processors are now in the business of reclaiming and upgrading the raw culm; however, their operations only scratch the surface of the available material. Basically, the culm represents more of a liability than an asset at the present time. The Pennsylvania Department of Environmental Resources (PaDER) periodically attempts to require the owners to limit acid water runoff into streams and groundwater by building 1 ined ponds.

Through the operational period to date, the fuel has been provided at no charge from a local anthracite processing operation. This operation purchases run-of-mine anthracite and upgrades it to high quality anthracite, producing culm as a waste byproduct. The rulm is then trucked several miles to a location for disposal. The plant has provided this material to the Shamokin FBC site at no charge because ic is conslderably closer than the normal disposal site and thus, their cost of culm disposal has been reduced. SAIC believes that culm could still be obtained from this source at no cost or at a very nominal charge for future operation. However, this source could only provide 50 to 75 percent of the culm required for continuous operation if the FBC boiler is operated at full load for an extended period of time. 
TABLE 2

SHAMOK.IN ANTHRACITE CULM-FIRED BOILER OPERATING SUMMARY

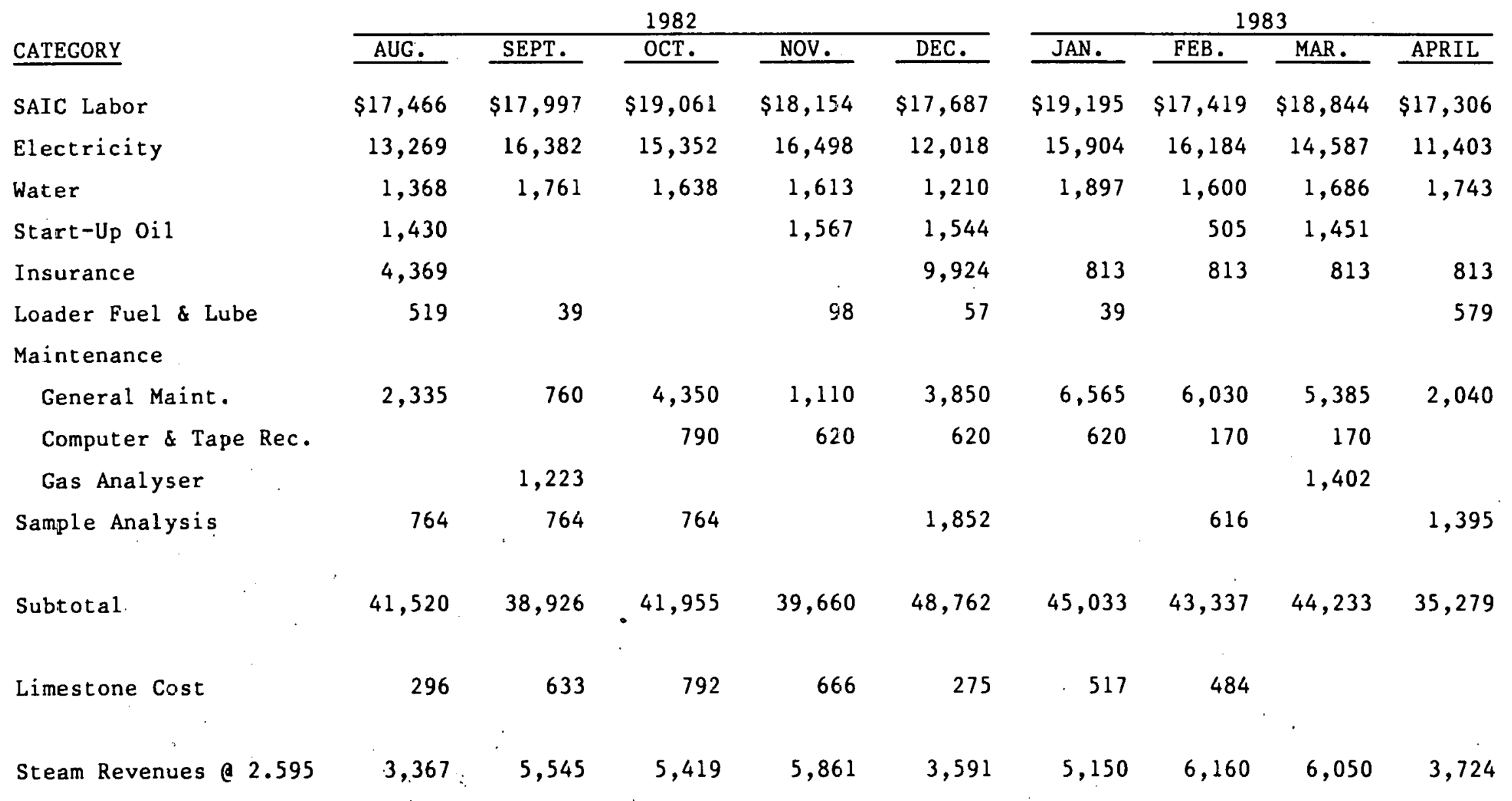


The above discussion provides an indication of why it is difficult to obtain a "fair market value" for anthracite culm. Basically there is no market for raw culm. Upgraded culm (i.e., culm which has been processed to improve heating value by removing ash and/or moisture) can be priced, but this material would exceed the Shamokin FBC boiler requirements. The upgrading adds considerably to the cost, with a non-linear relationship existing between heating value and cost; i.e., cost goes up more rapidly than does heating value.

At the present time, SAIC receives anthracite culm free of charge delivered to the site. Discussions with SAIC personnel indicate that SAIC could obtain all the raw culm that the FBC unit could fire at a cost of $\$ 2.00$ per ton delivered to the site. They have seen prices of $\$ 2.60$ per ton for culm that has been crushed by the vendor, but not upgraded in heating value. They stress that such prices must be negotiated. As there is no market, owners do not know what is a reasonable charge and a wide range of quotes will be obtained. Potentially, anthracite culm represents a significant energy resource in the local geographical area. However, more of a market must develop before prices will firm up. Based on SAIC's estimate, a full commercial operation "base case" cost of $\$ 2.00$ per ton for anthracite culm was utilized.

The anthracite culm fired at the plant has varied considerably in composition and heating value. Table 3 lists the design fuel analysis with the actual range of analyses encountered during parametric testing.(1) Additionally, the table shows the midpoint values which were used in this report.

Limestone: Limestone was provided from a local source. This limestone represented a low-grade material for which the supplier had no other use. Most of the $\$ 5.50$ per ton cost was associated with the requirement that the material be crushed and sized by the 
TABLE 3

ULTIMATE ANALYSIS OF SHAMOKIN ANTHRACITE CULM(1)

Design

$\begin{array}{lr}\text { Carbon \% } & 27.02 \\ \text { Hydrogen \% } & 1.42 \\ \text { Nitrogen \% } & 0.66 \\ \text { Oxygen \% } & 3.48 \\ \text { Sulfur \% } & 0.57 \\ \text { Ash \% } & 66.85\end{array}$

HHV, Btu/1b 4198
Actual

$$
\begin{array}{r}
24.15-26.59 \\
0.89-1.04 \\
0.47-0.56 \\
3.06-5.33 \\
0.73-0.94 \\
67.3-69.3
\end{array}
$$$$
3918-4164
$$

Average

25.37

0.965

0.515

4.195

0.835

68.12

4041 
supplier and delivered via a pneumatic truck. SAIC believes that this price is reasonable for future operations as well. Table 4 gives a typical analysis of the 1 imestone.

Ash Disposal: The historical base case shows no cost for ash disposal, since through the present time, ash has been temporarily stored at the site. If the unit is restarted for extended operation, the waste material would have to be permanently disposed. Several options have been identified.

Option $A$, the +50 mesh material has been approved by the Feniisylvalia Depalluenl of Transpurialiun as an anci-skid macerial. Thie potential market for 30 to 40 percent of the material produced (most of the bottom ash) could be sold at a price of $\$ 2.00$ to $\$ 4.00$ per ton. Some additional classification of the bottom ash might be needed to remove excess fines.

Option B, both the FBC flyash and bottom ash could potentially be utilized as extenders in cement and other limestone related products. The major criterion for this application is that the carbon content must be less than two percent. Thus, the total ash generated or the flyash not sold as anti-skid material could be utilized. It is anticipated that no charge could be made for such an extender and the user would haul the material away at no charge to the FBC boiler.

Option $C$, it has been brought to PaDER's attention that FBC ash is basic, not acidic, and that heavy metals do not leach as from conventional fly ash. PaDER is considering changing the claseification of FBC ash matcrial to allow the material to be "returned to the hole" from which it was removed. This would apparently be implemented as a part of the reclamation plan for the mining operation, and would help neutralize acid water runoff from 
TABLE 4

TYPICAL LIMESTONE ANALYSIS

Total $\mathrm{CaO}, \%$

Available $\mathrm{CaO}, \%$

$\mathrm{MgO}, \%$

$\mathrm{Na}$, ppm

$\mathrm{K}, \cdot \mathrm{ppm}$

$\mathrm{Fe}, \%$

$\mathrm{Al}_{2} \mathrm{O}_{3}, \%$

$\mathrm{SiO}_{2}, \%$

Acid Insolubles, \%

C1, ppm

Acid Evolution $\mathrm{CO}_{2}, \%$

LOI a $1000^{\circ} \mathrm{C}, \%$
37.15

0.095

1.92

248

242

1.37

2.31

15.86

22.55

200

31.73

32.22 
these operations. Such a disposal method would not involve landfill tipping fees, as discussed below, but would require hauling of the ash to the disposal site and placing it as directed by the mining operator. A charge of $\$ 2.00$ per ton would cover hauling for a one-way distance of 20 miles or less for this method of disposal.

Option D, the material could be disposed of at an approved landfill as is normally accomplished with conventional flyash. Under normal circumstances obtaining an ash disposal cost by this method would not prosent a problcm. Disposal chacges, or lipping fees, would be obtained from approved landfills in the area, with trucking charges added to obcain an ash disposal cost. As of July 1, 1983, all of the landfills in the immediate Shamokin area were closed as they were not in compliance with PaDER regulations. In the future either these landfills will be brought into compliance and reopened or new landfills will be constructed. The future charges will be higher than any historical charges.

Requirements for landfill disposal are manadated by PaDER regulations (see Appendix A). Any approved landfill must meet these requirements. As there are currently no approved landfills in the Shamokin area, representative costs were obtained for landfill disposal from other sources. Fluidyne. Fngineering Corporation provided their projected cost of landfill disposal for the FBC boiler currently under construction at East Stroudsburg State University. Their cost will be $\$ 3.27$ per cubic yard (approximately one ton/cubic yard) for disposal plus $\$ 3.00$ per ton to truck a distance of approximately 30 miles. This total cost of approximately $\$ 6.27$ per ton seems reasonable for landfill disposal. Fluidyne is also considering the options of use as an anti-skid material and/or as an extender.

In calculations for full commercial operation of the FBC boiler, the Option C cost of $\$ 2.00$ per ton was applied. This cost represents a compromise between the extremes of selling the material and 1 andfill 
disposal. The effect of varying the cost of ash disposal is discussed in the sensitivity analysis.

Electrical Power Cost: The historical average electrical charges and usage along with the estimated full load charge and usage are given in Table 5. The historical and estimated full load electrical charges were used to establish a linear relationship between the steam flow and electrical cost.

The average steam flow for the most recent nine months of operation was $8730 \mathrm{pph}$. The full design boiler flow rate is $23,400 \mathrm{pph}$ with $3400 \mathrm{pph}$ being used internally by the deaerator, yielding a net steam flow of $20,000 \mathrm{pph}$. Thus, the power charges were fit with the linear equation relating power cost to steam flow rates. The equation used is given in Table 5 .

Water Cost: The average and estimated full load water cost is given in Table 6. The water usage is actually about twice that required for boiler feedwater, with the balance being used for sanitary and miscellaneous items. The water consumption was also fit with a linear equation, since additional usage will probably vary fairly linearly with load. The equation generated is included in Table 6 .

Other Variable Costs: The additional cost factors of general maintenance, computer supplies/service, and front end loader operation/maintenance will also vary approximately with average boiler load. These items were lumped together to yield an "other variable" linear equation as shown in Table 7 .

Fixed Cost: Such items as operating labor, startup fuel oil, insurance, sample analyses, and gas analyzer system maintenance are cssentially independent of operating load. These fixed cost items are summarized in Table 8. As seen, the operating labor is the largest factor in the fixed cost. 
TABLE 5

ELECTRIC POWER COSTS

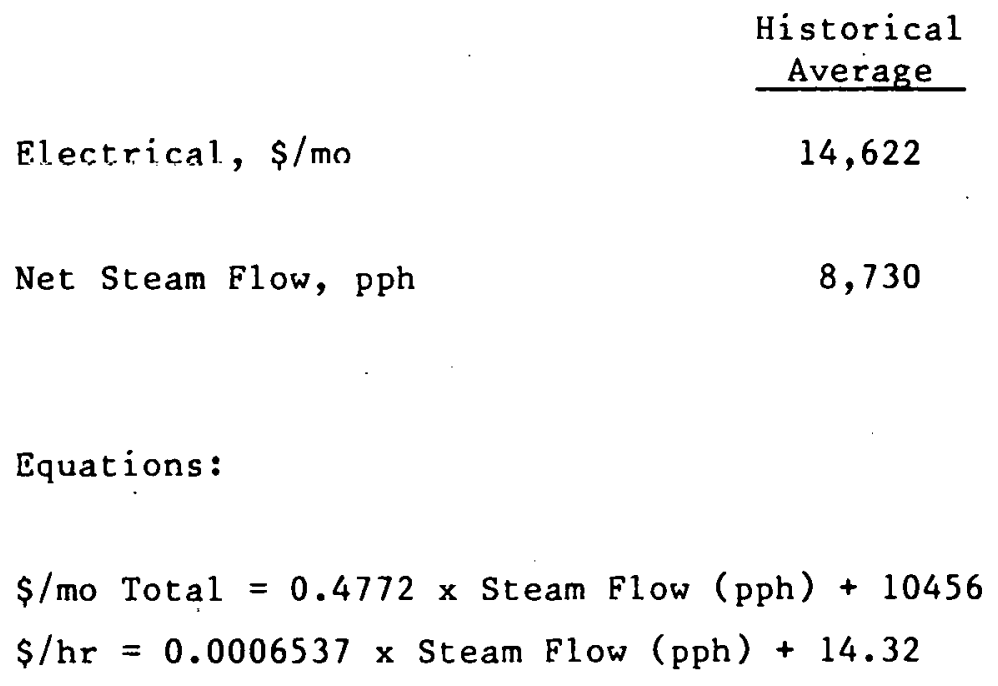

Equations :

$\$ /$ mo Total $=0.4772 \times$ Steam Flow $(\mathrm{pph})+10456$

$\$ / \mathrm{hr}=0.0006537 \times$ Steam Flow $(\mathrm{pph})+14.32$

TABLE 6

WATER COSTS

Hijcurical

Eulimalu Fú

Average

Full Load

Water, $\$ / m o$

1,613

3,200

Net Steam Flow, pph

8,730

20,000

Equations :

$\$ /$ mo Total $=0.1408 \times$ Steam Flow $(p p h)+383.70$

$\$ / h r=0.0001929 \times$ steam Elow $(\mathrm{pph})+0.5256$ 
TABLE 7

OTHER VARIABLE COSTS

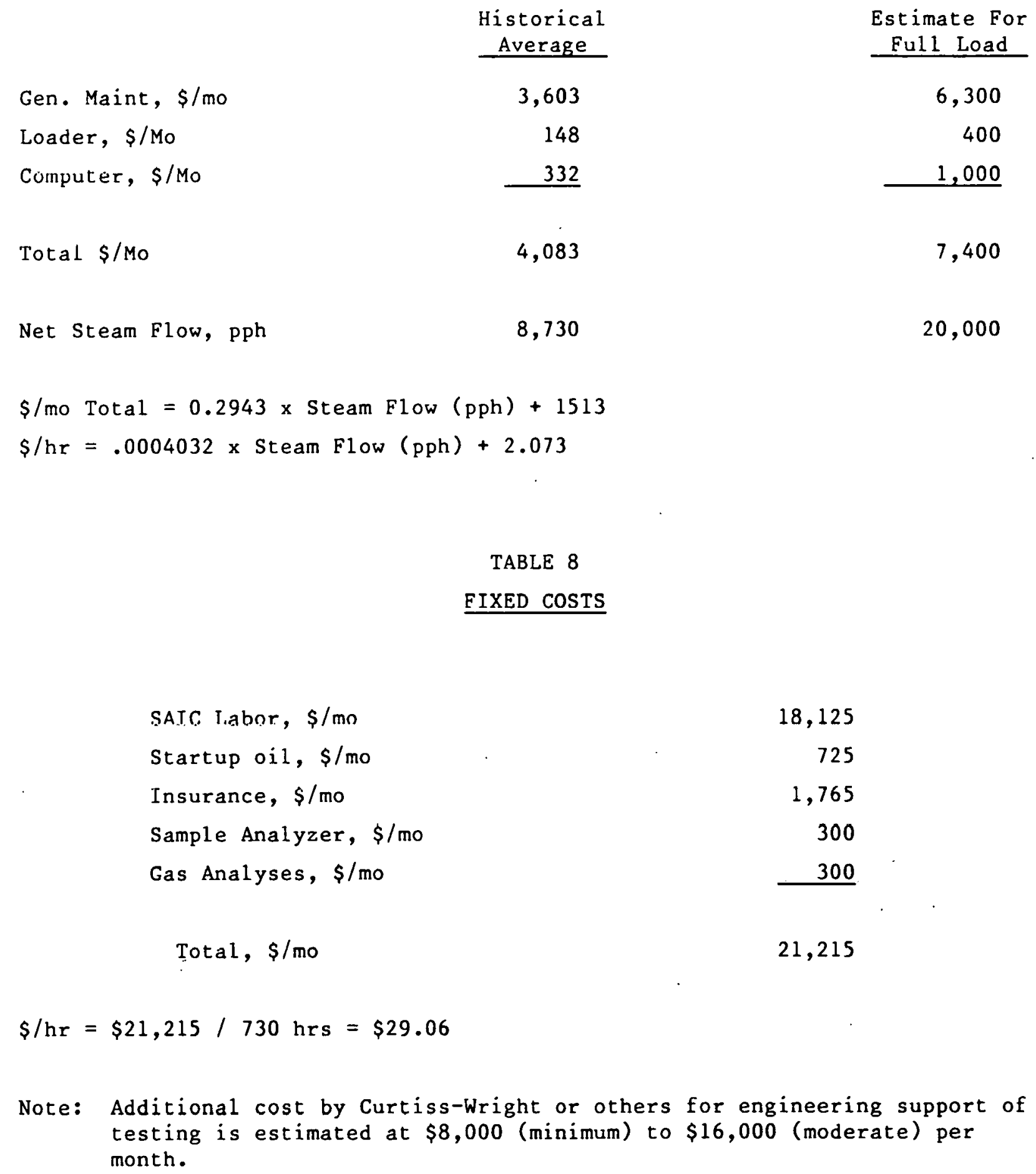


Steam Revenues: The current single customer for the steam generated by the plant has a negotiated charge rate of $\$ 3.48$ per thousand pounds of steam purchased. Additionally, the customer was allowed a 25 percent credit because he was required to maintain his own backup boiler and it was anticipated that the availability of the demonstration boiler might prove to be low. This brought his net rate to $\$ 2.595$ per 1000 ib steam. An additional factor that should be considered is that the customer's actual usage has been considerably lower than originally planned, averaging only approximatcly $3000 \mathrm{pph}$. This has kept actual tevenues lower thau anticipated tor the plant.

Assuming that a customer could be found who could utilize a larger quantity of the steam produced, a key factor would be the determination of the fair market value of the steam. Gilbert/Commonwealth's data indicate that industrial customers in the eastern Pennsylvania area are paying $\$ 5$ to $\$ 6$ per million Btu's for natural gas. Thus, a steam charge in the range of $\$ 5$ to $\$ 6$ per $1000 \mathrm{lb}$ steam would seem reasonable. This is discussed further in the following sections.

Plant Availability: The plant availability experienced during the extended test was provided by Curtiss-Wright and is shown in Table 9. The cumulative availability experienced during the nine months was 92.5 percent, which was used in this study.

Boiler Efficiency: The parametric test data are still being analyzed by Dorr 01 iver and Curtiss-Wright and boiler performance data have not been published. Howcver, preliminary data indicated full load etticiency was in the 70 percent range. For this study, the design efficiency of 73.5 percent was used. 
TABLE 9

SHAMOKIN ANTHRACITE CULM BOILER

EXTENDED TEST PLANT AVAILABILITY

Period

Aug. 9 - Aug. 31, 1982

Sept. 1 - Sept. 30

Oct. 1 - Oct. 31

*(Water \& Elect. Service Interrupted to Plant)
Hours

Run

$\underline{\text { (Fluidized) }}$

540

718

$736.5 \%$

720

368

679

744

91.

Replaced Baghouse bags

\& Seals

Feb. 1 - Feb. 28

Mar. 1 - Mar. 31

Installed Cyclone Recycle

Pipe Extension

April 1 - April 30, 1983

Evaluated Bituminous

Waste \& Low Temp.

Start on Culm
Hours

Available

540

720

744

720

100.

$558^{(1)}$

66 .

100.

99.
Availability

100.

672

672

100 .

668.5

744

90.

528.5

$648^{(2)}$

82 .

Cumulative

(1) Excludes planned shutdown for refractory installation

(2) Excludes planned investigation of low temperature ignition of culm 
4.0 OPERATING COST PROJECTIONS - HISTORICAL OPERATIONS

In this section estimates are provided of the operating costs for the Shamokin Fluidized Bed Combustion demonstration facility, using assumptions based upon conditions similar to conditions achieved during the recent nine-month demonstration operation.

4.1 OPERATING COST ESTIMATE

The design capacity of the Shamokin tluidized bed boiler is $23,400 \mathrm{pph}$ of saturated steam at $200 \mathrm{psig}$. Of this steam, $3400 \mathrm{pph}$ is used internally by the deaerator, leaving a net amount available for export of $20,000 \mathrm{pph}$.

During recent operation, the Shamokin unit was only able to sell an average of $3000 \mathrm{pph}$ of steam. Additionally, the negotiated selling price of the steam was low, basically to reflect an uncertainty as to the reliability of the demonstration boiler. This has resulted in net revenues from steam sales which were significantly below the theoretical revenues of the unit.

A factor to consider is there are a few bottlenecks still remaining at the plant that prohibit long-term, continuous operation at full load. Notable among these considerations is that the baghouse operation is not acceptable at full load, this limiting operation to 75 percent of full load at the present time. An increase in baghouse size to decrease the air-to-cloth ratio would be required to allow full load operation of the baghouse. A combination of limited funds and a lack of demand for full steam production has prohibited modifications necessary to achieve full load operation.

The culm being fired at the facility was delivered to the site at no charge. This might continue in the future, depending upon what arrangements could be negotiated with the culm suppliers, at least for a portion of the culm. It is more likely that some charge would 
be made for the culm for a long-term production operation. It should be noted that in order to deliver $3000 \mathrm{pph}$ of steam it was necessary to operate the boiler at a higher load, since this load was below the minimum turndown of the facility. This has adversely affected the operating cost of the unit as compared to the actual revenues. However, the effect was not as great as it would have been if the culm had not been provided free.

During operation to date, the ash generated from the system (i.e., fly ash and bottom ash) has been stored in a temporary storage area located at the site.

The 88 percent $\mathrm{SO}_{2}$ removal quoted in the unit operational permit and which was achieved is considerably higher than required for operation of similar capacity boilers in this area. Also, the facility has conducted a number of parametric tests since startup. Therefore, the historical $\mathrm{Ca} / \mathrm{S}$ has been fairly high, averaging about 4 .

The historical base case is based upon conditions similar to conditions achieved during the recent nine-month demonstration operation including those described above. The assumption is made that customers could be found for a higher flow rate of steam. Also, it is assumed that no modifications would be made to the system so that maximum capacity would still-be limited to the current maximum of approximately 15,000 pph net or 75 percent load factor. Other conditions for the historical case are given in Table 10. This case is representative of conditions that would be encountered if the unit is restarted in its current configuration. It should be noted that before the plant can be restarted some overhaul work, primarily to the I.D. fan and ash removal system, would be necessary. Curtiss-Wright(2) estimated that the cost of these items would be $\$ 75,000$. 
TABLE 10

\title{
BASE CASE PARAMETERS
}

Historical

\author{
Load Factor $=0.750$ \\ Availability $=0.925$ \\ Steam Production Factor $=0.694$ \\ Internal Steam Use $=2,550 \mathrm{lb} / \mathrm{hr}$ \\ Export Steam $=15,0001 \mathrm{~b} / \mathrm{hr}$ \\ Boiler Efficiency $=0.735$ \\ $\mathrm{Ca} / \mathrm{S}$ Ratio $=4.0$ \\ HHV Culm $=4041 \mathrm{Btu} / 1 \mathrm{~b}$
}

Limestone Cost $=\$ 5.50 /$ ton

Culm Cost $=$

0.00

Ash Disposal Cost $=0.00$ 
A breakdown of the components of the operating cost is given in Table 11 for the historical base case. The largest components of the cost are labor and electricity. All other items are relatively small. To significantly reduce the operating cost, either the labor or electrical costs, or both, must be reduced.

4.2 COMPARISONS WITH PROJECTED COSTS AND REVENUES

Operating costs were projected for the Shamokin plant for two purposes. One was to assess the economic feasibility of the concept and the other was for budget planning purposes for operations. In this section, both types of projected costs are compared to the actual costs and the major discrepancies are discussed.

In August 1979, a study was completed which compared the capital and operating costs of steam for a $20,000,50,000$, and $100,0001 \mathrm{~b} / \mathrm{hr}$ FBC boiler using anthracite culm as a fuel source. (3) The capital cost of the $20,0001 \mathrm{~b} / \mathrm{hr}$ boiler was arrived at from the actual equipment cost and estimated engineering and installation costs at Shamokin. The operating costs for the FBC boiler included all raw material such as culm, limestone, chemicals, and water, and all other elements of cost such as electricity, labor, and maintenance. The projected unit costs used are listed as follows:

\begin{tabular}{lll}
\multicolumn{1}{c}{ Item } & \multicolumn{1}{c}{ Unit } & Dollar \\
\cline { 2 - 3 } Culm & Ton & 1.00 \\
Limestone & Ton & 4.50 \\
Chemical & Per 10001 bs H2O & 0.20 \\
Water & $1000 \mathrm{gal} \mathrm{H}_{2} \mathrm{O}$ & 1.20 \\
Electricity & Kwh & 0.03 \\
*Labor & Hour & 8.00
\end{tabular}

*This is average labor cost including 70 percent overhead. 
TABLE 11

HISTORICAL BASE CASE - COST BREAKDOWN

Fixed Cost

\begin{tabular}{|c|c|c|}
\hline & s/year & $\%$ \\
\hline SAIC Labor & 217,500 & 37.77 \\
\hline Startup Oil & 8,700 & 1.55 \\
\hline Insurance & 21,180 & 3.68 \\
\hline Sample Analysis & 3,600 & 0.63 \\
\hline Gas Analyzer & 3,600 & 0.63 \\
\hline Total Fixed Cost & 254,580 & 44.21 \\
\hline \multicolumn{3}{|c|}{ Variable Cost } \\
\hline Culm Cost & 0 & 0 \\
\hline Ash Disposal & 0 & 0 \\
\hline Limestone Cost & 21,135 & 3.67 \\
\hline Electricity & 204,900 & 35.58 \\
\hline Waler & 28,050 & 4.87 \\
\hline Loader & 3,170 & 0.55 \\
\hline General Maintenance & 56,380 & 9.79 \\
\hline Computer & 7,660 & 1.33 \\
\hline Total Variable Cost & 321,295 & 55.79 \\
\hline Total Annual Cost & 575,875 & 100.00 \\
\hline \multicolumn{3}{|l|}{ Potential Steam Revenue } \\
\hline (e $\$ 6.00$ per $10001 \mathrm{~b})$ & 729,270 & \\
\hline Net Revenue & 153,395 & \\
\hline
\end{tabular}


Table 12 compares the yearly operation and maintenance costs projected from this study to projected costs for commercial operation. It assumes that the unit would be modified as needed to achieve full-load continuous operation and that the full quantity of steam produced could be sold.

A major difference in the two cost estimates was the unit costs used for culm, ash disposal, and electricity. The 1979 study used $\$ 1$ per ton for culm and ash disposal and $3 c$ per kwh for electricity; this study used $\$ 2$ per ton for culm and ash disposal and $5 c$ per kwh for electricity. The rationales for the culm and ash disposal costs were discussed previously. The cost for electricity was based on SAIC's actual cost during the extended test period. The other major difference was in maintenance costs, this study's estimate being based on the actual costs during the extended test period. Since the extended test lasted only nine months, some deferrable maincenance may not have appeared, making this estimate slightly low. The differences resulted in this study's estimate of operations and maintenance cost for continuous full load operation being approximately 12.5 percent higher than in the previous study. Basically, projected operations costs from the 1979 study are not significantly different from this study based on actual costs.

The second comparison shows the budgeted versus actual amounts spent during the nine month extended test period. The budgeted numbers were obtained trom an internal DOE report. Eighteen months of extended testing had been planned from mid-March 1982 to mid-September 1983. However, only nine months were actually run, from August 1982 to April 1983. Table 13 compares the budget versus actual amounts for the nine months of extended testing.

Budgeted items that were significantly higher included insurance, electricity, and water. Both electricity and water use were considerably higher than anticipated. Maintenance was lower than 
TABLE 12

PROJECTED OPERATIONS AND MAINTENANCE COSTS

$(20,0001 \mathrm{~b} / \mathrm{hr}$ net Culm Fired Boiler)

1979 Study

Labor
Startup Oil

Culm

Asli Dispousal.

Limestone

Electricity

Water

Loader Fuel and Lube

Maintenance

Total

Cost, 1,000 1b steam
$\$ 218,781$

$-$

32,412

32,412

17,827

168,542

29,171

$-$

136,130

653,993

4.04
This Study

$\$ 217,500$

21,180

63,893

49,214

17,632

231,410

35,865

4,400

86,305

736,099

4.54 


\section{TABLE 13}

BUDGETED VERSUS ACTUAL COST

EXTENDED TEST PERIOD

(August 1982 - Apri1 1983)

\begin{tabular}{lrr} 
& Budget & Actual \\
\cline { 2 - 3 } SAIC Labor & 171,246 & 163,125 \\
Insurance & 6,990 & 15,885 \\
Startup Oil & 12,408 & 6,498 \\
Startup Coal & 1,000 & 0 \\
Culm & $*$ & 0 \\
Ash Disposal & $*$ & 0 \\
Limestone & $*$ & 5,554 \\
Electricity & 108,973 & 131,598 \\
Water & 7,577 & 14,517 \\
Loader Fuel \& Lube & 0 & 1,332 \\
Maintenance & 51,075 & 26,533 \\
$\quad$ General & 3,566 & 2,988 \\
Computer & 3,634 & 2,628 \\
Gas Analyzer & 3,516 & 5,894 \\
Chemicals & 9,374 & 6,156 \\
Sample Analysis & & \\
Total Cost & 374,359 & 382,708 \\
Steam Revenues & 84,399 & 44,867 \\
Net Cost & 289,960 & 332,287
\end{tabular}

$*$ Non-budgeted items, SAIC provided as cost sharing. 
budgeted, reflecting, perhaps, deferrable maintenance which was not done. The actual total cost of operations and maintenance during the extended test period came to 2.2 percent over budget which is not a significant difference. The steam revenues were $10 \mathrm{w}$, since the customer only took about 50 percent of the steam that had been anticipated. This resulted in a net cost 15 percent greater than budgeted. 
In this section estimates are provided of the operating costs for the Shamokin Fluidized Bed demonstration facility for two different options concerning future operations. The first option assumes continued operation in the current configuration with, however, a charge for culm and ash removal. The second option assumes that the plant is reconfigured so that excess steam can be used to generate power. Calculations are also provided of the required selling price of steam in order for the facility to break-even on an operational basis, and a sensitivity analysis of key factors is also presented.

5.1 OPERATING COST ESTIMATE - PRESENT CONFIGURATION

This option assumes that the unit would be modified as needed to achieve full-load continuous operation and that the full quantity of steam produced could be sold. Ihis condition would be representative of full commercial operation of the facility.

There are several differences between this option and the historical operations discussed in Section 4.0. Previously, the culm being fired at the facility was delivered to the site at no charge. It is likely that some charge would be made for the cillm for a long-term production operation. A $\$ 2.00 /$ ton charge for culm was assumed.

During piior uperation, the ash generated from the system (i.e., fly ash and bottom ash) was stored in a temporary storage area located at the site. If the unit is to be restarted for commercial operation,-some arrangement must be made for disposal of the ash generated. Thus, for restart conditions, an allowance should be made for ash disposal. It is possible that a buyer might be found for the bottom ash which is less fine than the fly ash. This is dependent upon the ability to locate such a buyer. 
In the event that a commercial restart is made, it may be possible to modify the operational permit and/or operate at as 10 a $\mathrm{Ca} / \mathrm{S}$ as possible to minimize cost. Based upon data plotted in Reference 1 , a $\mathrm{Ca} / \mathrm{s}$ of 2.5 appears reasonable for a restart condition.

There are a few bottlenecks still remaining at the plant that would prohibit long-term, continuous operation at full load. Notable among these considerations is that the baghouse operation is not acceptable at full load. An increase in baghouse size to decrease the air-to-cloth ratio would be required to allow full load operation of the baghouse. A combination of 1 imited funds and a lack of demand for full steam production has prohibited making the modifications necessary to achieve full load operation. Curtiss-Wright (3) estimated that the cost of these items would be:

ID Fan Overhaul

Ash Removal Dust Suppression \& Misc. Increased Baghousc Capacity Prepared Culm Storage Shed \& Handling Improved Material for Ash Conveyor System Contingency $(10 \%)$
$\$ 25,000$

50,000 $105, \mathrm{nnn}$

65,000

1), 000

$\frac{26,000}{\$ 286,000}$

Base case parameters used for the full commercial operation option are summarized in Table 14.

A breakdowh of the cumpunenls of the uperating cost is given in Table 15 for the commercial operation base case. As witli the historical base case, the largest components of the cost would be labor and electricity. All other items would be relatively small. To significaully educe the operating coot, either the labor hr electrical costs, or both, would have to be reduced. 
TABLE 14

BASE CASE PARAMETERS

Full Commercial Operation

Load Factor $=1.000$

Limestone Cost $=\$ 5.50 /$ ton

Availability $=0.925$

Culm Cost $=\quad 2.00 /$ ton

Steam Production Factor $=0.925$

Ash Disposal Cost $=2.00 /$ ton

Internal Steam Use $=3,4001 \mathrm{~b} / \mathrm{hr}$

Export Steam $=20,0001 \mathrm{~b} / \mathrm{hr}$

Boiler Efficiency $=0.735$

$\mathrm{Ca} / \mathrm{S}$ Ratio $=2.5$

HHV Culm $=4041 \mathrm{Btu} / 1 \mathrm{~b}$ 
TABLE 15

COMMERCIAL OPERATION BASE CASE - COST BREAKDOWN

Fixed Cost

SAIC Labor

Startup Oil

Insurance

Sample Analysis

Gas Analyzer

Total Fixed Cost

\begin{tabular}{rr} 
\$1/year & \multicolumn{1}{c}{$\%$} \\
\cline { 2 - 2 } 217,500 & 29.55 \\
8,700 & 1.18 \\
21,180 & 2.88 \\
3,600 & 0.49 \\
3,600 & 0.49 \\
\hline
\end{tabular}

254,580

34.58

Variable Cost

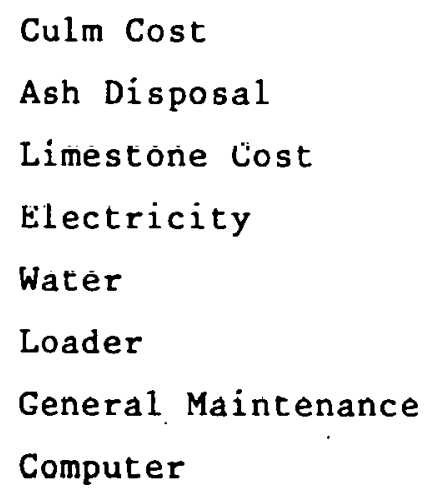

8.68

6.69

2.40

31.44

4.87

0.60

9.26

1.48

$481,519 \quad 65.42$

$\begin{array}{ll}736,099 & 100.00\end{array}$

4.54

972,360

236,261 
Figure 3 shows a plot of annual operating cost versus potential revenues for various steam selling prices. Also plotted is the estimated annual operating cost for the commercial operation conditions. It is significant to note that the current steam selling price would be too low to recover full operating costs even at full steam flow. Selling prices of $\$ 5$ to $\$ 6$ per $10001 \mathrm{~b}$ of steam would allow the unit to break even or generate a small profit (excluding capital charges) at high steam production factors.

Figure 4 shows the necessary selling price needed to break-even on an operations and maintenance basis at various steam production rates for both the historical and commercial operation base cases. The break-even point for the commercial operation case is higher since both culm and waste disposal costs are assumed. Also included for comparison are the predicted and budgeted operations cost for the Shamokin facility. (3) This plot graphically illustrates the necessity to sell reasonably large quantities of steam to break-even. An average steam production of $11,5001 \mathrm{~b} / \mathrm{hr}$ of steam would allow a break-even selling price of $\$ 6.00$ per $1000 \mathrm{lb}$ of steam. This appears to be both a reasonable price and to be well within the generating capability of the unit.

\subsection{SENSITIVITY ANALYSIS - PRESENT CONFIGURATION}

The previous sections have presented estimates of the operating cost of the Shamokin FBC demonstration plant. In generating the figures a series of assumptions were made as itemized in Table 14, Base Case Parameters for the Full Commercial Operation case. In this section a sensitivity study is presented that shows the effect of changes in the Base Case Parameters upon the economics of the plant. A number of terms are used to represent the parameters considered in the sensitivity analysis. Definitions of these terms are included in Appendix D. 


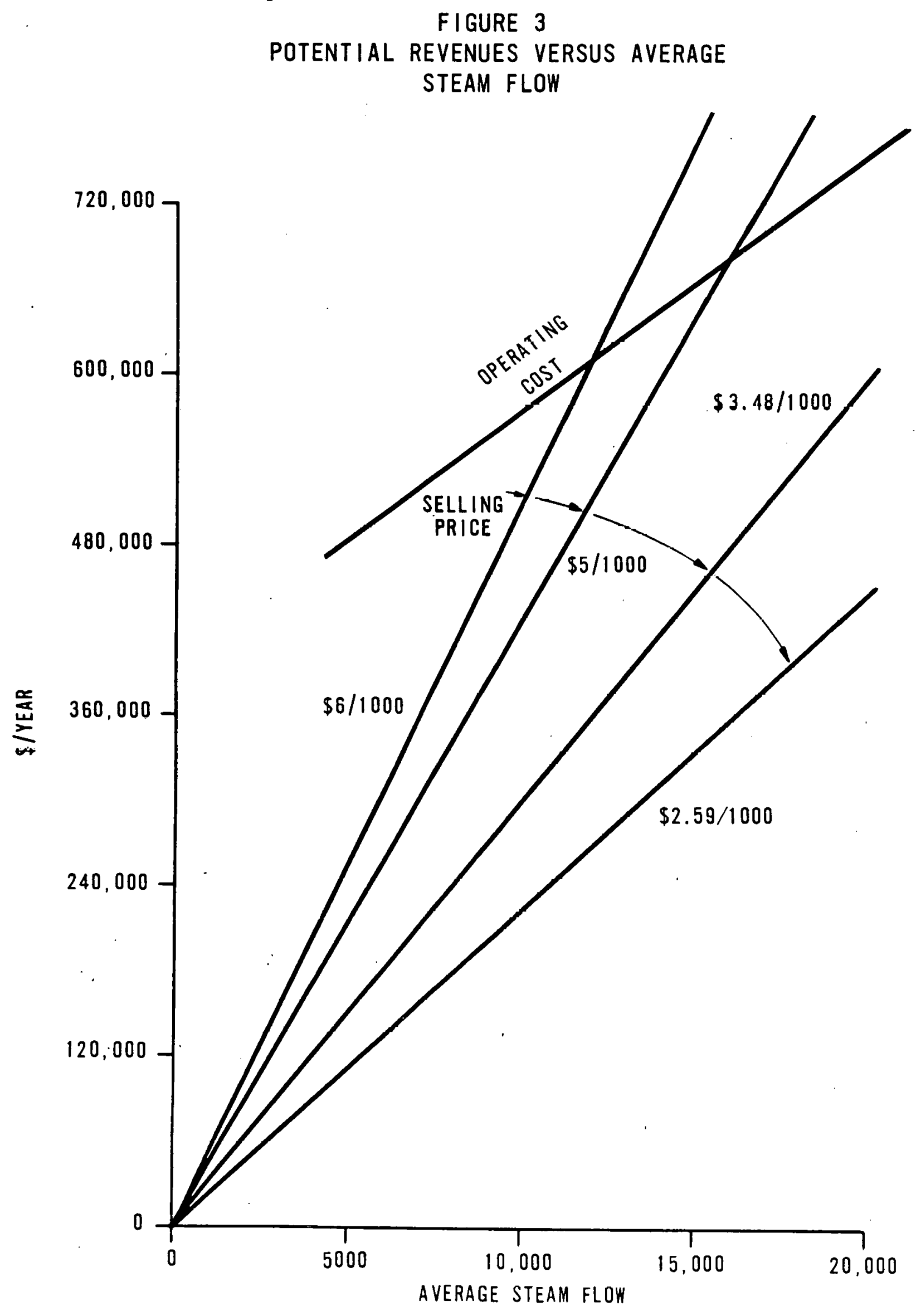


FIGURE 4.

BREAKEVEN PRICE VERSUS

STEAM PRODUCTION

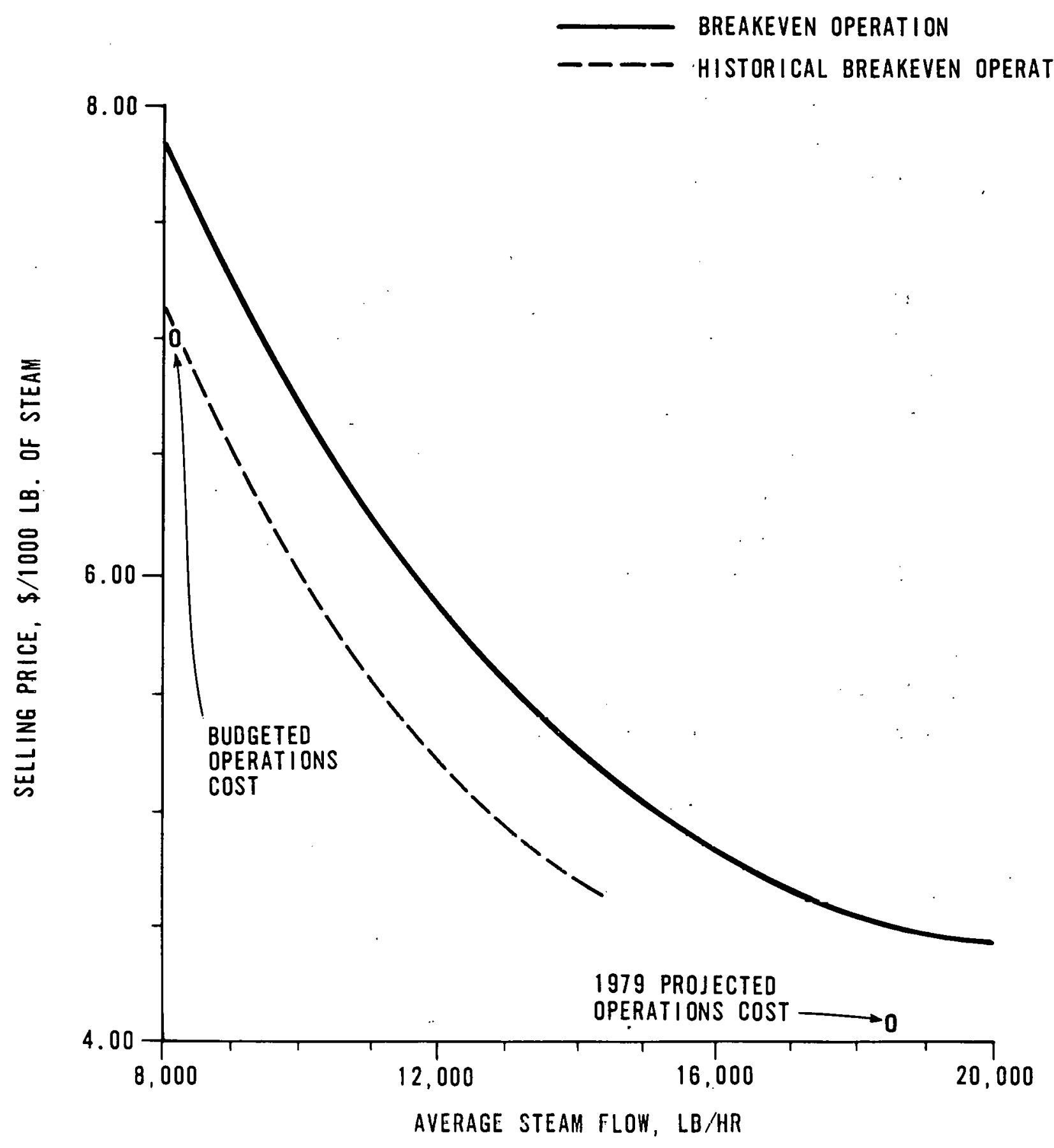


The sensitivity analysis was performed to determine the effect upon the operating cost of variations in several key parameters. This analysis provides information as to areas that might be modified in order to lower operating costs or otherwise improve revenues.

Table 16 summarizes results of calculations of operating costs for the commercial operating case. Sample calculations are provided in Appendix $B$ and complete printouts are shown in Appendix $C$. In these cases, the base load factor is 1.00 , the $\mathrm{Ca} / \mathrm{S}$ is 2.5 and culm cost and ash disposal cost are $\$ 2.00$ per ton of material for each. The load factor of 1.00 assumes that the plant has been modified to allow continuous full load operation.

Figure 5 shows a plot of operating cost in dollars per hour versus steam production factor (SPF). The operating cost would increase essentially linearly with increases in the steam production factor. Figure 6 shows a plot of operating cost in $\$ / 10001 \mathrm{~b}$ steam versus steam production factor. This figure shows the sensitivity of the required selling price of steam to the steam production factor. As seen from Figure 6 or Table 19, for steam production and sales of 18,000 pph or greater (i.e., SPF $=0.9$ ), the break-even steam selling price could be as low as $\$ 4.60$ per $10001 \mathrm{~b}$ steam.

$\Lambda$ review of Table 16 shows the operating cost is not very sensitive to either boiler efficiency or calcium-to-sulfur ratio. Relatively large changes in these parameters cause only small changes in operating cost.

The operating cost is quite sensitive to both culm cost and ash disposal cost, however. Operating costs, expressed either in $\$ / t$ ime or $\$ / 1000 \mathrm{lb}$ steam, increase linearly and rapidly with increases in either culm or ash disposal cost. 
TABLE 16

SENSITIVITY SUMMARIES -

CUMMEKICAL OPERATION

\begin{tabular}{|c|c|c|c|c|c|}
\hline Case No.* & Load Factor & $\begin{array}{l}\text { Steam Cost, } \\
\$ / 10001 \mathrm{~b} \\
\end{array}$ & Case No.* & $\begin{array}{l}\text { Limestone } \\
\text { Cost; S s/ton }\end{array}$ & $\begin{array}{l}\text { Steam Cost, } \\
\$ / 10001 \mathrm{~b} \\
\end{array}$ \\
\hline 41 & 0.50 & 6.66 & 79 & 0.00 & 4.43 \\
\hline 42 & 0.55 & 6.24 & 80 & 2.00 & 4.47 \\
\hline 43 & 0.60 & 5.89 & 81 & 4.00 & 4.51 \\
\hline 44 & 0.65 & 5.59 & 36 & 5.50 & 4.54 \\
\hline 45 & 0.70 & 5.34 & 82 & 6.00 & 4.55 \\
\hline 46 & 0.75 & 5.12 & 83 & 8.00 & 4.59 \\
\hline 47 & 0.80 & 4.93 & 84 & 10.00 & 4.63 \\
\hline 48 & 0.85 & 4.76 & 85 & 12.00 & 4.67 \\
\hline 49 & 0.90 & 4.61 & 86 & 14.00 & 4.71 \\
\hline 36 & 0.925 & 4.54 & 87 & 16.00 & 4.75 \\
\hline \multirow[t]{2}{*}{50} & 0.95 & 4.48 & 88 & 18.00 & 4.79 \\
\hline & & & 89 & 20.00 & 4.83. \\
\hline
\end{tabular}

\begin{tabular}{|c|c|c|c|c|c|}
\hline Case No.* & Boiler Eff & $\begin{array}{l}\text { Steam Cost, } \\
\$ / 10001 \mathrm{~b}\end{array}$ & Case No.\# & $\mathrm{Ca} / \mathrm{s}$ & $\begin{array}{c}\text { Steam Cost, } \\
\$ / 10001 \mathrm{~b}\end{array}$ \\
\hline 51 & 0.60 & 4.72 & 56 & 0.0 & 4.41 \\
\hline 52 & 0.65 & 4.65 & 57 & 1.0 & 4.46 \\
\hline 53 & 0.70 & 4.58 & 58 & 2.0 & 4.52 \\
\hline 36 & 0.735 & 4.54 & 36 & 2.5 & 4.54 \\
\hline 54 & 0.75 & 4.53 & 59 & 3.0 & 4.57 \\
\hline \multirow[t]{2}{*}{55} & 0.80 & 4.48 & 60 & 4.0 & 4.62 \\
\hline & & & 61 & 5.0 & $4.68^{\circ}$ \\
\hline
\end{tabular}

* Case No. 36 is the base case; for complete details see printout in Appendix $\mathrm{C}-1$. 


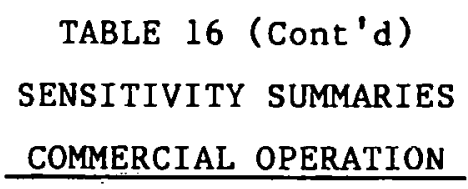

\begin{tabular}{c} 
Case No.* \\
\hline 62 \\
36 \\
64 \\
65 \\
66 \\
67 \\
68 \\
69 \\
70 \\
71 \\
72
\end{tabular}

Culm Cost, s/ton

Steam Cost, $\$ / 10001 \mathrm{~b}$

0.00
2.00
4.00
6.00
8.00
10.00
12.00
14.00
16.00
18.00
20.00

4.15

4.54

4.94

5.33

3.73

6.12

6.51

6.91

7.30

7.70

8.09

Case No.*

73

36

75 :

76

77

78

Case No. $\div$

36

90

yi

92

93

\section{Ash Disposal, $\$ /$ ton}

0.00

2.00

4.00

6.00

8.00

10.00

Power Factor

1.00

.75

.50

.25

0.00
Steam Cost, $\$ / 10001 \mathrm{~b}$

$$
\begin{aligned}
& 4.24 \\
& 4.54 \\
& 4.85 \\
& 5.15 \\
& 5.45 \\
& 5.76
\end{aligned}
$$

Steam Cost, $\$ / 10001 \mathrm{~b}$

$$
\begin{aligned}
& 4.54 \\
& 4.13 \\
& 3.73 \\
& 3.33 \\
& 2.93
\end{aligned}
$$


TABLE 16 (Cont'd)

SENSITIVITY SUMMARIES

COMMERCIAL OPERATION

Case No.*

36

94

95
Labor Factor

1.00

.75

.50
Steam Cost, $\$ / 10001 \mathrm{~b}$

4.54

4.19

3.86 
FIGURE 5

OPERATING COST VS STEAM PRODUCTION FACTOR

RESTART CASE

( $\$$ PER HOUR)

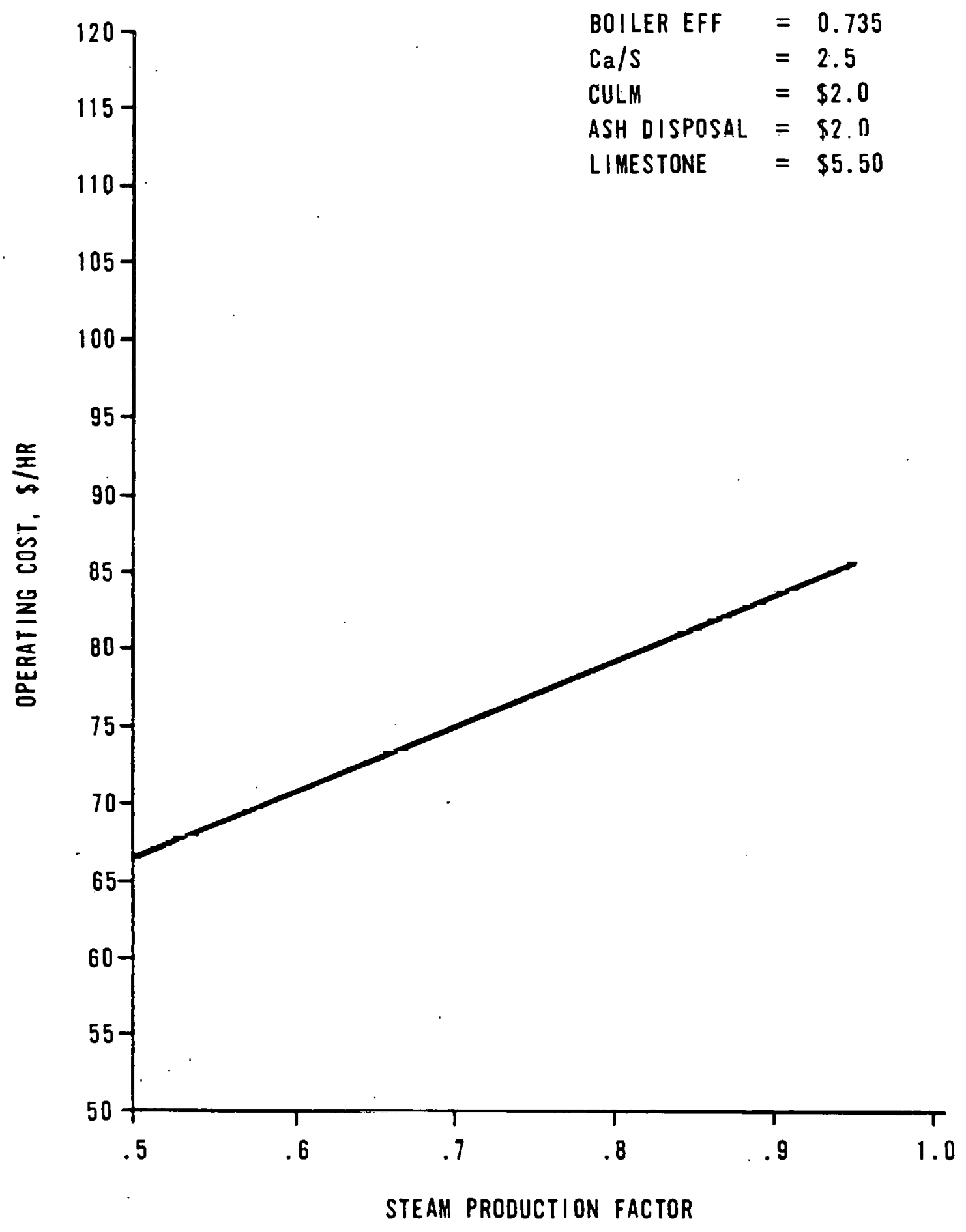


FIGURE 6

OPERATING COST VS STEAM PRODUCTION FACTOR RESTART CASE

(\$ PER 1000 LB. STEAM)

$\begin{array}{ll}\text { BOILER EFF } & =0.735 \\ \text { Ca/S } & =2.5 \\ \text { CULM } & =\$ 2.0 \\ \text { ASH DISPOSAL } & =\$ 2.0 \\ \text { LIMESTONE } & =\$ 5.50\end{array}$

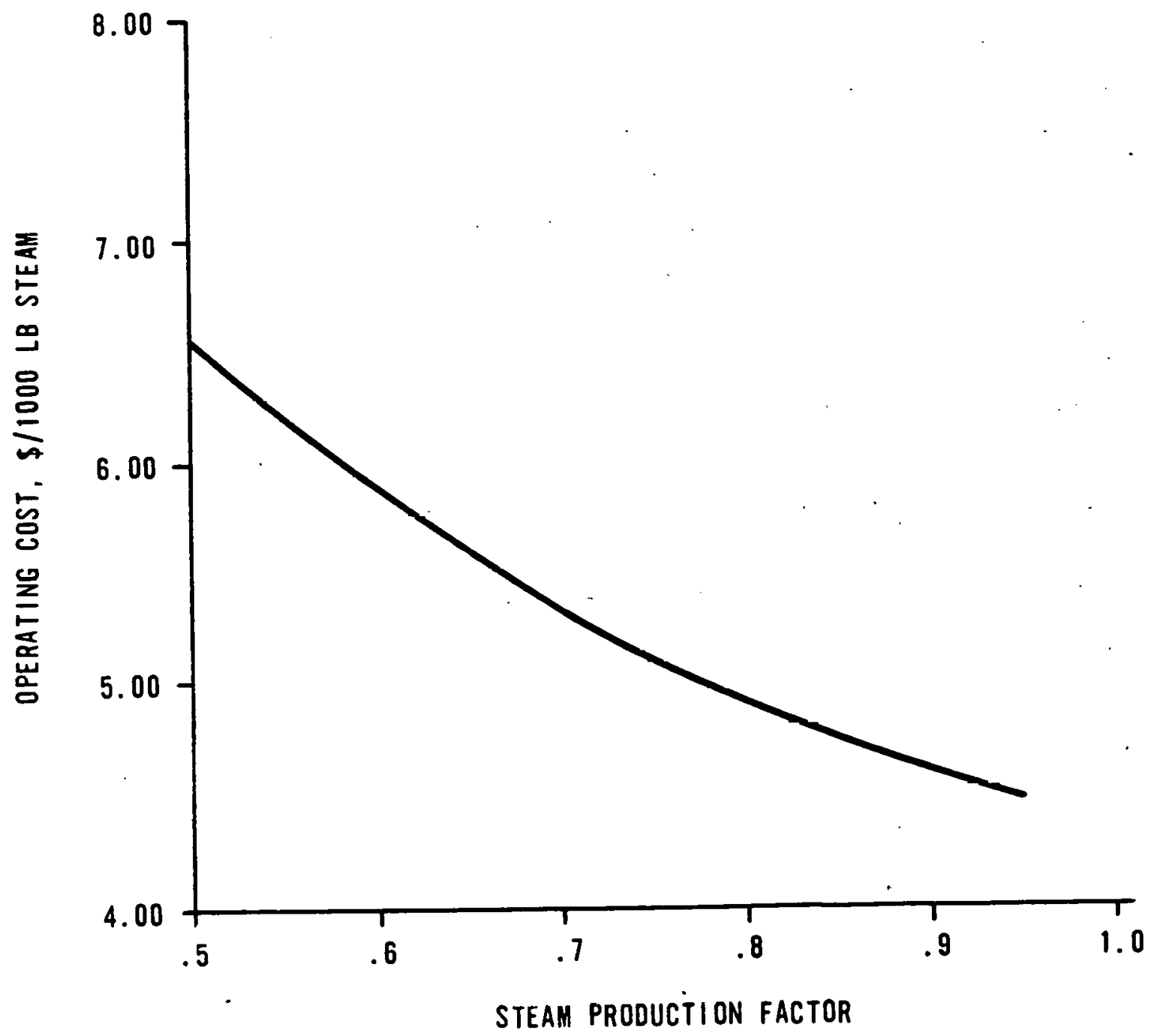


The electrical power factor and the labor factor show strong effects upon the cost of steam as seen in the last two entries of Table 16. These factors represent fractions of current cost levels with reductions obtained by either lowering rates or reducing usage. As noted previously, power and labor represent major fractions of the total plant operating cost. Therefore, the strong sensitivity to these factors is understandable.

5.3 OPERATING COST ESTIMATES - RECONFIGURED PLANT

Since the sale of significantly more steam is not likely in the near future, an investigation was made into the feasibility and economics of reconfiguring the plant for cogeneration.

It must be pointed out that cogeneration was not an initial design goal of the system, rather, the objective was to verify the ability to fire anthracite culm in an FBC boiler. The size of the boiler and steam conditions were established to meet requirements of the smallest size required to verify operation and provide the appropriate steam conditions for customer needs. The unit is simply too small and steam conditions too moderate for good cogeneration. Since steam sales have, to date, provell lo be too low to support continued operation, cogeneration has been examined as a possible alternate to keep the unit operating.

In considering cogeneration, a number of assumptions were made. For the base case, all applicable paramcters (i.e., conts of limestone, culm, ash disposal, Ca/s, builer efficiency, etc.) were ronsidered to be the same as for full commercial operation (Table 14). Additionally, it was necessarye to consider the selling price of steam, quantity of steam sold, purchase and selling price of power, 
turbine generator efficiency, and steam and condenser conditions. The base case cogeneration conditions are listed below.

Selling Price of Steam
Quantity of Steam Sold
Purchase Price of Power
Selling Price of Power
Turbine Generator Efficiency

$$
\begin{aligned}
& \$ 6.00 \text { per } 10001 \mathrm{~b} \\
& 30001 \mathrm{~b} / \mathrm{hr} \\
& \$ 0.05 / \mathrm{kWh} \\
& \$ 0.06 / \mathrm{kWh}
\end{aligned}
$$

0.70 .

Variations of the above parameters are considered in the sensitivity analysis, Section 5.4 .

A special "sell back" rate would be available from the electric utility for power generated from culm. The utility would purchase power at $\$ .06$ per kWhr from a cogeneration facility using culm for fuel. Therefore, an advantage could be realized if all the excess steam was used to generate electrical power, the power sold to the utility at $\$ .06$ per $\mathrm{kWhr}$, and the power required for plant operation purchased back from the utility at $\$ .05$ per $\mathrm{kWh} r$ (present energy cost).

An investigation was made to find turbine-generator equipment on the secondary market, since purchasing new equipment from a manufacturer would be extremely expensive. The investigation discovered a suitable system, surplus equipment owned by an Elmira, New York, supplier. The supplier was able to quote on a "never used" G.E. turbine-generator suitable for use at the shamokin facility. The supplier could furnish the turbine-generator, an air cooled condenser system, switchgear, and all turbine controls for $\$ 455,000$ (1983 price). The unit would generate a maximum of $1000 \mathrm{~kW}$, utilizing 200 psig saturated steam at the throttle and condensing at atmospheric pressure with an air cooled condenser. 
The budgetary capital cost for the installation of the turbine generator and air cooled condenser is estimated to be:

Turbine-Generator and Condenser

Foundations (Bldg. \& Equipment)

Building $\left(30^{\prime} \times 50^{\prime} \times 16^{\prime}\right.$ high)

Equipment Setting

Piping, Valves, and Condensate System

Electrical

$$
\begin{array}{r}
\$ 455,000 \\
25,000 \\
36,000 \\
10,000 \\
100,000 \\
80,000 \\
\hline
\end{array}
$$

Total $\$ 706,000$

This is in addition to the $\$ 286,000$ estimated to be needed to bring the plant up to full load operation making the full cost $\$ 992,000$.

The steam generator would be capable of producing 23,400 $1 \mathrm{bs}$ per hour of 200 psig saturated steam. A total of 3,000 lbs per hour could be sold to a local manufacturer. The balance of the steam could be used to generate electricity and to heat deaerator water. Assuming that 20,000 lbs per hour of condensate could be recovered (neglecting losses), $3000 \mathrm{lbs}$ per hour of feedwater would have to be made-up to the system. This feedwater would have to be heated to deaerator temperature along with the condensate return. It would take approximately 825 lbs per hour of steam to effect this. Consequently, the net amount of steam available for electrical generation would be 19,575 lbs per hour. The turbine generator proposed could generate approximately $780 \mathrm{~kW}$ with this steam input. A 92.5 percent availability would drop the average hourly generation to $724 \mathrm{~kW}$.

A breakdown of the components of the operating cost is given in Table 17 for the reconfigured plant base case. The analysis shows that the net revenue that could be received from plant operations would be $\$ 230,500$ less than operating costs. This approach, while reducing the operating deficit, is not economically feasible. 
TABLE 17

RECONFIGURED PLANT BASE CASE - OPERATING COST BREAKDOWN

Fixed Cost

SAIC Labor

s/year

$\%$

Startup Oil

217,500

28.72

8,700

1.15

Insurance

21,180

2.80

Sample Analysis

3,600

0.48

Gas Analyzer

3,600

0.48

Total Fixed Cost

254,580

33.63

Variable Cost

Culm Cost
Ash Disposal
Limestone Cost
Electricity
Water
Loader
General Maintenance
Computer

Total Cost

Steam Revenue

Power Revenue

Net Revenue
64,040

8.46

49,320

6.52

17,700

2.34

244,940

32.36

37,970

5.02

4,660

$0.6 ?$

72,170

9.53

11,570

1.53

502,370

66.37

756,950

100.00
145,850

380,620

$(230,480)$ 
The air cooled condenser considered above presents the lowest capital cost option for cogeneration, but does not present the best thermodynamic cycle. Options were considered to improve the efficiency of the cycle by utilization of a water cooled condenser and adding superheat to the steam. These options would potentially decrease the deficit in operating costs but would require greater capital expenditures. In no case considered would sufficient revenues be generated to amortize the capital investment.

5.4 SENSITIVITY ANALYSIS - RECONFIGURED PLANT

In examining the sensitivity of cogeneration options, a new set of parameters was considered. The basic costs of culm, limestone, ash disposal, $\mathrm{Ca} / \mathrm{S}$, load factor, boiler efficiency, and availability remained as in the commercial operating cases examined. Additionally, however, it was necessary to consider the selling price of steam, quantity of steam sold, selling price of power, and turbine generator efficiency.

Table 18 summarizes calculated net revenues for a series uf conditions including culm cost, ash disposal cost, power price, sleain price, and the amount of steam snld. Sample calculations are found in Appendix B and complete printouts are shown in Appendix C. Base case conditions were taken as close as possible to the commercial operating conditions, i.e., load factor $=1.00$, avallabilily $=0.925$, etc.

Additionally, the base case for cogeneration assumes that $3000 \mathrm{pph}$ of steam (i.e., the historical demand) would be sold at $\$ 6.00$ per $1000 \mathrm{lb}$ of steam. The balance of available steam would be sent to the turbine generator. Since the selling price of the steam would be significantly greater than the selling price of power that could be generated with the steam in all cases, this represents the most profitable case. 
TABLE 18

\section{SENSITIVITY SUMMARIES - RECONFIGURED PLANT}

\begin{tabular}{|c|c|c|c|c|c|c|}
\hline Case No.* & $\mathrm{Cu} 1 \mathrm{~m}$ & Cost, $\$ /$ ton & $\begin{array}{l}\text { Net Revenues } \\
\$ / \mathrm{hr} \\
\end{array}$ & Case No.* & $\begin{array}{l}\text { Steam Sold } \\
\text { pph }\end{array}$ & $\begin{array}{l}\text { Net Revenues } \\
\$ / h r\end{array}$ \\
\hline 1 & & 1.00 & -22.66 & 2 & 3000 & $-26 \cdot 31$ \\
\hline 2 & & 2.00 & -26.31 & 11 & 4000 & -22.98 \\
\hline 3 & & 3.00 & -29.97 & 12 & 5000 & -19.65 \\
\hline 4 & & 4.00 & -33.62 & 13 & 6000 & $-16 \cdot 32$ \\
\hline 5 & & 5.00 & -37.27 & 14 & 7000 & -12.99 \\
\hline 6 & & 6.00 & -40.93 & 15 & 8000 & -9.66 \\
\hline \multirow[t]{7}{*}{7} & & 7.00 & -44.58 & 16 & 9000 & -6.33 \\
\hline & & & & 22 & 10,000 & -3.00 \\
\hline & & & & 23 & 11,000 & +0.33 \\
\hline & & & & 24 & 12,000 & 3.66 \\
\hline & & & . & 25 & 13,000 & 6.99 \\
\hline & & & & 26 & 14,000 & 10.32 \\
\hline & & & & 27 & 15,000 & 13.65 \\
\hline
\end{tabular}

\begin{tabular}{|c|c|c|}
\hline Case No.: & $\begin{array}{c}\text { Ash Disposal } \\
S / \text { ton }\end{array}$ & $\begin{array}{l}\text { Net Revenues } \\
\$ / \mathrm{hr}\end{array}$ \\
\hline 8 & 6.50 & -38.98 \\
\hline 9 & 3.10 & -29.41 \\
\hline 2 & 2.00 & -26.31 \\
\hline 10 & -.80 & -18.43 \\
\hline
\end{tabular}

\begin{tabular}{|c|c|c|}
\hline Case No.* & $\begin{array}{l}\text { Steam Price } \\
\$ / 10001 \mathrm{~b}\end{array}$ & $\begin{array}{l}\text { Net Revenues } \\
\mathrm{S} / \mathrm{hr}\end{array}$ \\
\hline 17 & 4.00 & -31.86 \\
\hline 2 & 6.00 & -26.31 \\
\hline 18 & 8.00 & -20.76 \\
\hline \multirow[t]{4}{*}{19} & 10.00 & -15.21 \\
\hline & 12.00 & -9.66 \\
\hline & 14.00 & -4.11 \\
\hline & 16.00 & 1.44 \\
\hline
\end{tabular}

*Case No. 2 is the base case; for complete details see printout in Appendix C-2. 
TABLE 18 (Cont'd)

SENSITIVITY SUMMARIES - RECONFIGURED PLANT

\begin{tabular}{|c|c|c|}
\hline Case No.* & $\begin{array}{c}\text { Power Price } \\
\$ / \mathrm{kWh} \\
\end{array}$ & $\begin{array}{c}\text { Net Revenues } \\
\mathrm{S} / \mathrm{hr} \\
\end{array}$ \\
\hline 21 & .04 & -40.79 \\
\hline 20 & .05 & -33.55 \\
\hline 2 & .06 & -26.31 \\
\hline
\end{tabular}

*Case No. 2 is the base case; for complete details see printout in Apperidix C-2. 
No combination of culm cost, ash disposal cost, and power price came close to breaking-even operationally. A steam price of approximately $\$ 15$ per $10001 \mathrm{~b}$ would be necessary to break-even operationally. The amount of steam that would have to be sold to break-even would be reduced slightly in the cogeneration option from 12,000 to 11,000 lb per hour. Under no conditions considered could the unit generate sufficient revenue to pay for the capital charges of the turbine generator and associated equipment.

In addition to reconfiguring the plant for cogeneration, which was discussed in Section 5.4, several other options were identified from the preceeding analysis which were felt to have the potential to improve overali plant economics. By far the greatest effect upon plant profitability could be obtained by increasing steam sales at a higher steam selling price. This option is discussed in Section 5.5.1: It should be noted that in all of the following considerations, maximum profitability would always be obtained at the maximum steam sales rate, since steam is the maximum value product from the facility.

The use of steam turbine drives for reducing electric power costs is considered in Section 5.5.2, 1 imestone usage reduction is considered in section 5.5.3, and labor reductions in 5.5 .4 .

Other possibilities to reduce operating costs, such as by improving boiler efficiency, were not considered since there is no practical method to accomplish this.

\subsubsection{Increase Steam Sales and/or Price}

The Shamokin Area Industrial Corporation has the objective of bringing new businesses into the Shamokin area. One of the incentives which they have used is the availability of steam from 
the Shamokin FBC demonstration boiler. Availability of this steam at an attractive price is une of the potential advantages for a business to locate in the Shamokin area.

The Shamokin area and, in general, the anthracite belt, have been economically depressed for a number of years. As a result, SAIC has not been successful in finding a new business to utilize the steam from this plant. The result is that only one customer is now available who can use the steam produced. This customer has only utilized an average of $3000 \mathrm{pph}$ in recent nperational periods. Although SAIC has been seeking, and will continue to seek, additinnal rustnmers, it is not likcly that they will be found in the near future.

A related question is, if customers could be found for a larger quantity of steam, what would be a "fair market price"? The current customer already owns a coal fired boiler which he maintains as a backup. It would be more common for a new business locating in the area to purchase an oil or gas fired package boiler to generate $20,000 \mathrm{pph}$ of $200 \mathrm{psig}$ steam, if the Shamokin FBC steam unit was nor. available. A coal fired boiler is an alternate; however, the capital cost and operating labor would be considerably higher, though the fuel cost would be lower.

Table 19 summarizes a budget estimate of the cost of steam generated from a $20,000 \mathrm{pph}$ oil or gas fired package boiler. These figures indicate thal il would cose a new business $\$ 9.52$ per $1000 \mathrm{lb}$ steam for gas lisillg ur $\$ 11.64$ per lử lb steam for oil firing to provide their own steam based upon the assumptions used in the calculations. A selling price below these figures should still be actractive to any new business.

SAIC has had some discussions with potential customers and has suggested a selling price of $\$ 6.00$ per $10001 \mathrm{~b}$ of steam. Based upon the above comparison to oil or gas fired boilers, this seems to be a rate that would be attractive to a new business. 
STEAM COST FROM OIL OR GAS FIRED BOILER

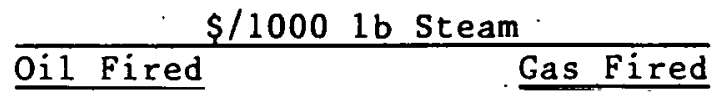

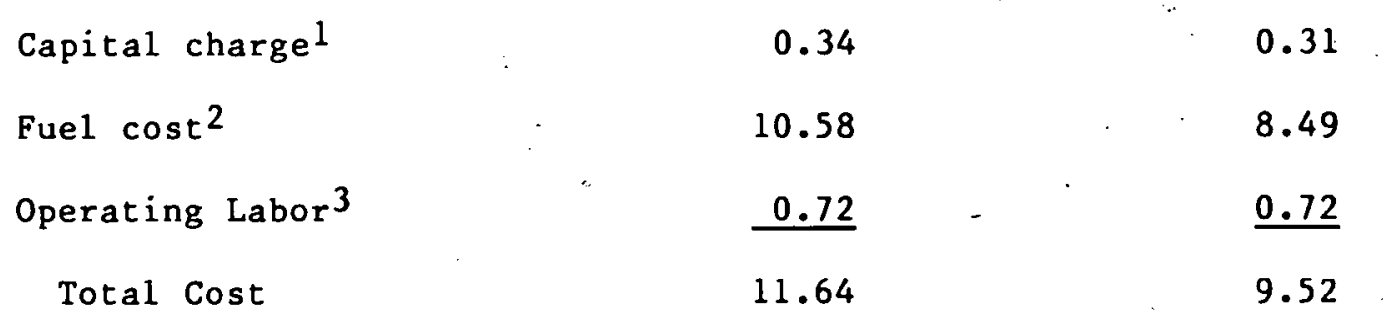

1 Capital charge based on budgetary estimate of $\$ 249,500$ for gas fired and $\$ 272,400$ for oil fired package boiler delivered and erected and 0.22 capitalization factor.

2 Fuel cost based on $\$ 5.50 / \mathrm{million}$ Btu for gas and $\$ 0.95 /$ gallon for oil. Boiler efficiency of 0.76 in both cases.

3 Based on a single boiler operator at $\$ 14.42$ per hour. 
5.5.2 Replacement of Electric Drives with Steam Turbine Drives

One of the options investigated to improve the plant operating economics was the replacement of electric motors with steam turbines to provide power for the major energy users at the facility. One of the feedwater pumps, now utilized as a standby, is driven by a steam turbine. It has a horsepower rating of 19 and a water rate of $53.41 \mathrm{bs}$ per horsepower. However, the turbine driven pump is only rated at two-thirds of the capacity required for operating the facility at maximum steam output. Twenty-eight horsepower would be required to provide the feedwater required al plant full load. If the standby pump was replaced with a steam turbine driven pump for full load, and the turbine had the same water rate (a normal turbine efficiency for this size of turbine), the steam required to operate the pump would be 1495 lbs per hour. Translating this requirement into operating cost, the annual expenditure for operating the feedwater pump at full boiler capacity would be $\$ 10,800$.

The cost of electric power to operate the feedwater pump at full luad uperation is $\$ 10,400$ per year, which is less than the cost with a steam turbine drive. It is estimated that the cost of procuring and installing a new feedwater pump, steam turbine drive, controla, steam piping, valves, and foundation would be $\$ 20,000$.

By comparing the two results, and considering the amortization of capital costs involved in acquiring and installing a new feedwater pump and turbine, the driving of the feedwater pump with steam would increase the operating cost of the facility.

The two largest energy users in the system are the fluidizing blower and the induced draft fan. The fluidizing blower uses 280 bhp at full load and the induced draft fan uses 140 bhp at full load.

If steam turbines were added to power the two blowers (in addition to the electric drives), a significant portion of the facility 
electrical consumption would be eliminated ( 60 percent). The water rate (i.e., efficiency) is better for the larger size steam turbines. A steam turbine having a water rate of $36 \mathrm{lb} / \mathrm{bhp}$ could be purchased for the fluidizing blower. Similarly, a turbine for the induced draft fan would require $36 \mathrm{lb} / \mathrm{bhp}$. These values are based on using 200 psig steam and exhausting at near atmospheric pressure. Therefore, 10,080 $1 \mathrm{bs} / \mathrm{hr}$ of steam would be required for the fluidizing blower and $5,040 \mathrm{lbs} / \mathrm{hr}$ of steam would be required for the induced draft fan to operate the facility at full load. The annual cost for operating both blowers with steam would be $\$ 108,800$ per year. The cost of operating the blowers with the existing electric drives at full load would be $\$ 156,400$ per year.

There would be a net savings of $\$ 47,600$ per year if steam turbines were used to drive the fluidizing blower and induced draft fan. However, this would only allow a net of $4880 \mathrm{lbs} / \mathrm{hr}$ of steam to be sold ( $3400 \mathrm{lbs} / \mathrm{hr}$ required for deaerator heating). At $\$ 6$ per $10001 \mathrm{bs}$ of steam, total plant revenue would be $\$ 237,300$ per year which would not cover plant fixed costs (labor, etc.) per year, based on full load generation disregarding fuel, ash, and capitalization costs. Retrofitting steam turbines to the existing blowers would cost a minimum of $\$ 55,000$ (turbines, new fan rotor shafting and couplings, steam piping, controls, and foundation modifications). Therefore, conversion to steam turbines is not a viable option.

\subsubsection{Reducing or Eliminating Limestone Feed}

A major goal of the Shamokin culm fired plant was to demonstrate sulfur capture in the bed with limestone. Experimental data have shown that an 88 percent reduction in sulfur dioxide emissions was possible with a reasonable $\mathrm{Ca} / \mathrm{s}$ ratio.(4) When burning the design anthracite culm with 0.57 percent sulfur, the $\mathrm{SO}_{2}$ emission rate would be $0.331 \mathrm{~b} / \mathrm{SO}_{2}$ per million Btu with an 88 percent reduction in emissions. The plant is subject to state emission regulations which 
allow an emission rate for this size plant of $4.01 \mathrm{~b} / \mathrm{SO}_{2}$ per million Btu. Thus, in theory, no $\mathrm{SO}_{2}$ control is necessary. However, since sulfur control was going to be demonstrated, an enforceable permit condition of $0.33 \mathrm{lb} / \mathrm{SO}_{2}$ per million $\mathrm{Btu}$ was included in the operational permit. To reduce or eliminate limestone feed, a change in the permit would be necessary.

If 1 imestone was eliminated, the plant's $\mathrm{SO}_{2}$ emissions would be above the allowable emissions that presently exempt it from PSD and emission offset regulations. The plant then would be subject to: (a) an air quality review, (b) an impact analysis, and (c) a best available control technology review.

In addition, the elimination of limestone would probably make the disposal of the culm ash more difficult. The excess limestone makes the ash basic, and, thus, less susceptible to heavy metal leaching. The request to PaDER for a favorable ruling on the disposal of this ash is predicated on limestone being in the ash.

The potential savings from the elimination of 1 imestone would be relatively small, 2.4 percent of the total operating costs. Because of the potential regulatory and waste disposal problems, elimination of the limestone would probably not be feasible. However, the historical $\mathrm{Ca} / \mathrm{S}$ ratio has been fairly high, averaging about 4 . In future operations, it may be possible to modify the operational permit and/or operate at lower $\mathrm{Ca} / \mathrm{S}$ ratios to reduce limestone costs.

\subsubsection{Operating Labor}

The plant operation staff included 12 persons. During the day shift, six persons were at the plant: two were assigned to materials handling, three for operations and maintenance, plus the plant manager. The three other shifts required for continuous operation had two persons each for operations and maintenance. This 
staffing would probably be adequate for boiler capacities up to the 50,000 to $100,000 \mathrm{lb} / \mathrm{hr}$ range. Above this capacity an additional material handling person would be needed per shift.

For the cogeneration case, no additional operating labor was assumed. If turbine operators are necessary, the labor requirements might increase to 16 . Table 20 shows the effect of these operating labor assumptions on annual operating costs. 
TABLE 20

EFFECT OF OPERATING LABOR REQUIREMENT ON OPERATING COS'I' (Continuous Operation Base Case)

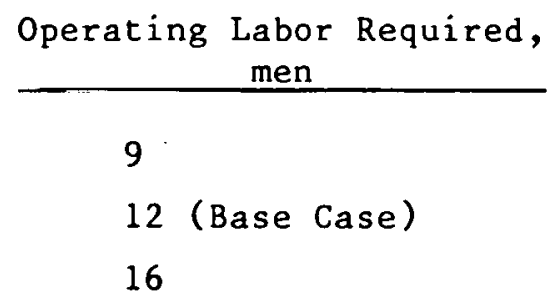
Annual Operating Costs, dollars

Steam Cost

$\$ / 10001 \mathrm{~b}$

681,720

4.21

736,099

4.54

808,595

4.99 
Based on the plant performance data, the operating cost estimates, and the cost sensitivity analysis, the following conciusions are made:

a. The Shamokin facility has demonstrated the technical ability to generate steam from anthracite culm with both a high reliability and reasonable operating cost. However, the current steam selling price is too low to recover full operating costs even at full steam flow. A steam selling price of approximately $\$ 6$ per $1000 \mathrm{lb}$ of steam would allow the unit to break-even on an operating and maintenance basis at steam sales rates of $11,5001 \mathrm{bs} / \mathrm{hr}$. This price should be very competitive if customers can be found.

b. Projected and actual operating costs show substantial agreement. The key factor that has resulted in less revenues for the facility is lower than expected steam revenues.

c. The largest contributors to operating costs are labor and electricity which each make up about 30 percent of operating costs. No other item makes up more than 10 percent of operating costs.

d. None of the cogeneration options could allow operation at "break-even," much less pay back the relatively large investments required for cogeneration. Essentially, the boiler is too small in capacity and design steam temperature and pressure is too low for the unit to be a cost effective power generator. No other system changes could be recommended which would reduce operating costs substantially.

e. Conversion of the electric drives to steam drives is not cost effective. 
1. D. G. Chiplaanker, et al., "Performance of a Fludized Bed Steam Generator Burning Anthracite Culm," presented at the 7th International Conference on Fluidized Bed Combustion, Philadelphia, Pa. October 25-27, 1982.

2. Personal communications from Fred Spindler, Curtiss-Wright to Mike Klett, Gilbert Associates.

3. "Design, Construction, Opcration and Evaluation of a Prototype rulm Combustor Boiler/Heater Unit: Teohnical and Economic Evaluation of Prototype and Larger Size Facility," Dorr-0liver Incorporated, Thermal Products Technology, Stanford, Connecticut, 06904, DOE Report FE-3269-14A, August 1979.

4. Leon, A. M., et al., "Combustion Studies Conducted in 12" Diameter Fluid Bed Facility," Dorr-0liver Incorporated, Thermal Products. Technology, Stanford, Connecticut, DOE Report FE-3269-9A, April 1979. 
APPENDIX A

LANDFILL, REGULATORY REQUIREMENTS FOR DISPOSAL OF ASH 
APPENDIX A

LANDFILL REGULATORY REQUIREMENTS FOR DISPOSAL OF ASH

I. INTRODUCTION

The Shamokin Area Industrial Corporation (SAIC) is reviewing operating requirements for an atmospheric fluidized bed anthracite culm combuster located at the Shamokin Area Industrial Park. Landfill disposal is required for an average of 30 cons/day and a maximum of 77 tons/day of ash. Distribution of ash is estimated to be 60 percent fly ash and 40 percent bottom ash.

Ash disposal presents a problem in the Shamokin area. As of July 1, 1983, all local landfills were closed by the Pennsylvania Department of Environmental Resources (DER). Alternative sites must be located, or the existing local landfills must be brought into compliance. The purpose of this review is to identify the regulatory requirements which must be considered in disposing of the aslı by landfill.

As with any solid waste disposal project, the initial approach to regulatory requirements for disposal of $\mathrm{HBC}$ ash consists of answering the following questions:

1. Are the wastes classified as hazardous or non-hazardous?

2. Is design and permitting of the facility governed by Federal regulations, state regulations, or a combination of both?

3. Are the wastes to be landfilled in an existing, permitted facility, or will design and licensing of a new facility be réquired. 
Solid wastes are classified as hazardous wastes if they are 1 isted hazardous wastes or if they exhibit the characteristics of hazardous wastes. Listed hazardous wastes and hazardous waste characteristics are presented by the EPA in $40 \mathrm{CFR} 261$ and by DER in $25 \mathrm{~Pa}$. Code 75.261. Defined hazardous waste characteristics are ignitability, corrosivity, reactivity, and EP (Extraction Procedure) toxicity.

Bottom ash and fly ash from fluidized bed combustors are not listed hazardous wastes. Ash from the FBC unit at Shamokin has not been tested specifically for the characteristics defining hazardous waste. However, FBC solid wastes in general are not ignitable or reactive. Although basic, an aqueous solution of the material would not be expected to exceed the $\mathrm{pH}$ limit of 12.5 defining corrosivity. Because of the basic nature of the material, leachate heavy metals concentrations are normally well under the EP toxicity limits.

EPA and PaDER specifically exclude certain wastes from being classified as hazardous wastes, regardless of their characteristics. Specifically excluded wastes include "fly ash waste, bottom ash waste, slag waste, and flue gas emission control waste generated either from the combustion of coal or other fossil fuels." This exclusion appears to be broad enough to include solid wastes from a fluidized bed combustor.

Considering the general characteristics of FBC wastes, along with the probability of qualifying for a specific exclusion, it is reasonable to assume that the $\mathrm{FBC}$ wastes from the unit at Shamokin are not hazardous wastes. As a result, discussion of 1 andfill permitting and design requirements will consider only non-hazardous wastes. 
Permitting and design requirements for hazardous waste landfills derive primarily from Federal regulations developed under the Resource Conservation and Recovery Act (RCRA). RCRA allows EPA to grant authorization to states to administer hazardous waste management programs which are equivalent to the Federal program.

RCRA leaves management of non-hazardous solid wastes primarily to state and local agencies. The primary effect of RCRA is to require states to adopt minimum standards to eliminate "open dumps." The operative standards governing permitting and design of landfill disposal of the Shamokin FBC wastes are those adopted by the Pennsylvania DER.

Current regulations governing solid waste management in Pennsylvania are contained in $25 \mathrm{~Pa}$. Code, Chapter 75. These regulations are primarily directed toward municipal solid waste, or "sanitary landfills." Subchapter 75.37 addresses standards for fly ash, bottom ash, or slag disposal areas, but not in a comprehensive manner.

In order to more adequately address non-municipal solid wastes, DER has issued for comment a set of draft guidelines for residual waste disposal. Residual waste is defined as "any garbage, refuse, other discarded material or other waste including solid, liquid, semisolid, or contained gaseous materials resulting from industrial, mining and agricultural operations and any sludge from an industrial, mining or agricultural water supply treatment facility, waste water treatment facility or air pollution control facility, provided that it is not hazardous." Both the current regulations and the draft guidelines are evaluated in the following sections. 
Residual wastes must meet the following minimum criteria as provided by draft $25 \mathrm{~Pa}$. Code, Chapter 283:

1. Residual waste shall be a minimum of twenty (20) percent solids by weight and non-fluid.

2. Residual waste shall have a $\mathrm{pH}$ of 5.0 to 11.0 .

3. Residual waste shall not be subject to spontaneous combustion under ambient atmosphere and temperature.

4. Residual waste shall be compatible with other solid wstes disposed of at the facility.

5. Leachate resulting from the residual waste shall be compatible with the design of the disposal facility.

V. INDUSTRIAL WASTE DISPOSAL AT PERMITTED SITES

Disposal of industrial solid wastes at sites previously permitted by Pennsylvania DER requires submittal and approval of Module No. 1, a copy of which is attached. Completion of Module No. 1 requires the following information:

1. Description of the manufacturing process(es) generating the waste(s) and a 1 ist of the raw materials as well as incermediates and final products contained in each waste.

2. An analysis of the waste itself and a leachate analysis of the waste. For a residual waste which is the sole waste deposited in a facility, the sample shall be prepared according to ASTM-Method A leaching analysis. For a residual waste which is to be disposed. of in any facility in which it will be mixed 
with other residual wastes or with municipal wastes, the sample shall be prepared in accordance with the EP toxicity or ASTM-Method B leaching analysis procedures.

3. Information about the disposal site, including location, ownership, disposal method, and design specifications.

4. Environmental assessment of disposal.

In determining whether to permit the disposal of a residual waste, such as the Shamokin FBC ash, at a specified disposal facility DER will evaluate the physical and chemical analysis of the residual waste, as well as the following factors:

1. Chemical quality of the residual waste to be disposed of in relation to the constituents in the waste as compared to the quantity of that waste;

2. Capabilities of the approved leachate treatment facilities;

3. Ability of the soil to attenuate the residual waste constituents in a natural attenuation site;

4. Compatibility of the residual waste with the liner in a lined site;

5. Waste handling practices at the disposal facility;

6. Healch and safery of the empluyees al the disposal facilily;

7. Quality and quantity of other residual waste being managed at the facility;

8. The quality of ground water in the area of the disposal facility; and 
9. Compliance of the disposal facility with DER rules and regulations.

The draft guidelines ( $25 \mathrm{~Pa}$. Code, Chapter 283) establish the suitability of certain types of disposal facilities for certain residual waste streams. The guidelines establish maximum chemical concentrations allowable in each type of residual waste disposal facility. Facilities are classified as Types I, II, III, and IV. Type I facilities provide the least amount of protection to the environment and Type IV facilities provide the greatest amount of protection to the environment.

Typical leachate characteristics for $F B C$ wastes indicate that the Shamokin FBC ash would be likely to be characterized as a Type II waste. Type II residual waste disposal facilities are thos designed in accordance with either Subchapter $E$ or Subchapter $G$ of draft Chapter 284. Type II facilities designed in accordance with Subchapter $G$ may only accept $f l y$ ash or bottom ash wastes. Type II facilities designed in accordance with Subchapter $E$ may accept any wastes suitable for Type I or Type II facilities. Type II wastes may also be disposed of in Type III or Type IV facilities, but probably at significantly higher costs.

Type II, Subchapter E facilities manage leachate by natural soil attenuation utilizing a maximum $2: 1$ ratio of solid waste to $\therefore$ : atcenuating soil. A minimum of eight feet of attenuating soil beneath the waste and above the seasonal high groundwater table is required.

Type II, Subchapter G facilities manage leachate by use of a soil drain and filter blanket system. This system is a network of pipes and drains which separately collect all perched water and leachate from the disposal facility and remove such waters to a central collection point for monitoring and for treatment, if necessary. Allowable depth of solid waste is limited only by stability and bearing capacity of underlying geologic foundation materials. 
Design and permitting of new solid waste landfills is currently regulated by $25 \mathrm{~Pa}$. Code, Chapter 75 . Specific requirements for fly ash, bottom ash, or slag disposal areas are presented in

Subchapter 75.37 . These regulations will eventually be replaced by draft Chapters 283 and 284, as previously discussed. Permit application requirements, currently a two-stage process, will remain largely unchanged.

Phase I of the Pennsylvania DER Solid Waste Management Permit Application is primarily for site approval, without describing the proposed facility in detail. Major elements of the Phase I application are:

1. Site ownership, location, zoning, etc.

2. Narrative description of the proposed operation, including solid waste types and quantities.

3. Chemical analysis of the solid waste.

4. Leachate testing and analysis.

5. Detailed geological and groundwater description of the site, inriluding logs of test borings and test pits.

6. Proposed groundwater monitoring system.

Following approval of the Phase I submittal, a Phase II applicatiun is prepared. Phase II includes detailed design information on the facility, including responses to any conditions attached to the Phase I approval. Major elemenls of the Phase II application arc:

1. Detailed drawings and specifications for landfill construction. 
2. Detailed operating plan.

3. Information on equipment, access roads, fire protection, vector control, water, communications, and employee facilities.

4. Soil Erosion and Sedimentation Control Plan.

5. Pollution Incident Prevention Plan.

Technical design requirements for a new site to accept $F B C$ ash are essentially the same as those for an existing, permitted site able to accept the same material. Obtaining approval to landfill a new solid waste at an existing, permitted site is a much simpler process than obtaining a permit for a new site. Economics will vary depending upon the site, but will generally favor an existing site because of significant engineering and facilities construction costs for a new site. 
1. Describe in detail on a separate sheet the manufacturing process(es) generating the waste(s) and list the raw materials as well as intermediatos and final products contained in each waste.

2. Include en analysis of the waste itself and a leachato analyses of the waste. The analyses must contain but need not be limited to the following parameters unless the applicant has specific knowledge of the absence of any of these parameters:

Percent Solids
pht
Cliernical Oxygen Demand
Tutal Organic Carbon
Oil/Grease
Total Dissolved Solids
Total Volatile Solids
Specific Conductance
Ammonia Nitrogen
Phenol
Cyanide

Arsenic
Cadmium
Copper
Chromium
Lead
Mercury
Molyudenum
Nickel
Selonium
Silver

If codisposal with municipal refuse is proposed, use ASTM Method B or EPA's extraction procedure for leaching the waste. Otherwise, use ASTM Method A. Use apprnpriate Stindard Methods of Analysis or EPA's methods for the chemicol analyses,

For the analysis of the wasto itsclf, use a nitric acid digestion for extraction of the metals. An organic analysis may be required if the waste contains appreciable amounts nf organirs. 
A. DISPOSAL SITE INFORMATION:

1. Facility Name:

2. Facility Location:

3. Focility Owner:

4. Facility Mailing Addreas:

5. Facility Manager:

Telephone No.

6. Facility Contact:

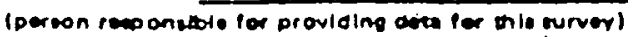

Teleptione No.

7. Does the facllity dlschargo industrial wastes to a municipal sowar rystem?

If yes, name of system

8. Does the site have a leactiato treatment focillty?

If yes, attach discharge standards.

8. If the site is andfill, attach last monitoring analysis. If last analysis is more than three (3) months prior, attach a current analysis to this module.

B. DESCRIPTION OF SPECIFIC WASTE:

1. Company orlgin of waste (name and address):

Company Contact: Telephone No.

2. Treatment: is waste conditioned prior to dlsposal? How?

3. Dispossl: Present Mothod

4. Provide and attach special characteristics of this waste which determine the method of disposal include chemical analysis, physical description, procent of water and leaching analysis relative to disposal proposal. Provide the date of all data submitted.

5. What difficulties do disposal of thls waste presently present?

6. What difflcultles are anticipated for the disposal of this waste in the future? 
7. What other processes can be used effectively?

8. Average Daily Volume

9. Annusl Volume

10. What process generated this waste? (Describe)

TABLE A - WASTE DESCRIPTIONS

11. CHECK APPROPRIATE CATEGORY

A. 1 Concentrated sulfuric acid solutions with heavy metal

A. 2 Concentrated mixed acids whth heavy metals

A.3 Dilute acid solutions containing hexavalent chromium ànd/or other oxldants

A.4 Dllute acid solutions containing heavy metals but ho hexavalent chromium or ammonia

A. 5 Dilute acid solutions contalning heevy metals and arnmonium salts

A.6 Açidic nitrate solutions containing heavy metals

A.7 Acidic wastes with hazardous metals except $\mathrm{Cr}^{+0}$

B.1 Alkaline solutlons containing cyanides

B.2 Alkaline solutions containing sulfides.

B.3 Concentrated alkaline solutions containing no sulfide nor cyanide

8.4 Miscellaneous alkaline solutions containing contaminants other than hazardous metals

8.5 Alkaline solutions containing hazarouds metals

C. 1 Combustible organic sludges, solids and liquids

C.2 Sludges. clurries and solids containing cyanitas

C.3 Sludges, slurries and solids containing hexavalent chromium

C.4 Inorganic sludges, slurries, solids containing no hexavalent chromium nor cyanide

C. 5 Wastewster contaminated with high concentrations or organic substances

C.6 Organic contaminated solids

C.7 Other (describe)

12. Phryical State At Ambient Temperature:

$\square$ Solid and non-pumpable liquid - solid mixtures

Liquid and pumpable liquid - solid inixtures 
COMMONWEALTH DF PENNSYLVANIA

DEPARTMENT OF ENVIIIONMENTAL RESOUNCES

BUREAU OF SOLID IVASTE MANAGEMENT

INDUSTRIAL WASTE DISPOSAL AT PERMITTED SITES

MODULE NO. 1
PEAMIT NUMBEN OF PROPOSEO OIBPOSAL SITE

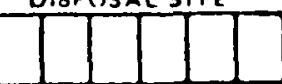

13. Primary Characreristic

Inorganic

$\square$ Acid

$\square$ Alkaline

$\square$ Cyanide

Filter Aids \& Clays

$\square$ Heavy Metal

-WWT Sludge

Pesticides

Catalyst

Other, describe
Organic

[] Oil \& Oily Sludge

$\square$ Paint \& Pigment Fesidue

$\square$ Plastic, Pasticizers, Resins,

Elastonier Residues

$\square$ Solvent

$\square$ "WWT Sludge

$\square$ Pesticides

[] Still Bottoms, Heavy Residue

$\square$ Pharmaceutical Waste

$\square$ Other, describe
Secondary Characteristic

[ $]$ Heavy Metals

$\varpi$ Other Motals

$\square$ Sulfides

Hexavalent Chromium

$\square$ Organic

$\square$ Halogenated

$\square$ Sulfonated

$\square$ inorganic

$\square$ Other, describe

14. Hozards
Toxic Substance
Poison
$\square$ Skin Irritant
$\square$ Explosive
$\square$ Respiratory Irritant
$\square$ Cercinogen
$\square$ Corrosive to Steel
Deactive, acid
[ ] Corrosive to Concrete
Reactive, water
[] Corrosive, other
$\square$ Reactive, other
$\square$ Flammable
Other, describe

Cyanogen

C. OISPOSAL METHOD: (describe applicable items)

Type of disposal (i.e., landfili, lagoon, pond, ctc.).

DESIGN SPECIFICATIONS.

1. Liner type (i.e., concrate, asphalt, clay. etc.) and thickness.

$\cdots$

2. Leachate collection and treatment capability at site for woste un lin disposod of. (Describe)

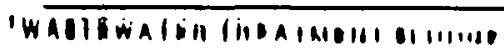


3. Methods of burial (i.e., mixing hazardous waste with other wastes, containerization, etc.)

4. Identify and describe method of transportation of the waste the site.

D. ENVIRONMENTAL ASSESSMENT OF DISPOSAL: State briefly the anticipated impact of disposal at the site and provide the data or substantiation for the stated conclusions.

E. ENGINEER.

1. Name

2. Address

$\longrightarrow-$

Telephone Number \& Area Code:

ACl 1

5 Seal of Registered Professional Engineer
3. Hegistration Number

4. Signature

5. Seal if Registered Prolessiconal Engineer

S. Ál 
APPENDIX B

SAMPLE CALCULATIONS 


\section{APPENDIX B}

SAMPLE CALCULATIONS

\section{Base Case Input:}

$\begin{array}{lll}\text { Availability } & & 0.925 \\ \text { Load Factor } & = & 1.00 \\ \text { Boiler Efficiency } & =0.735 \text { percent } \\ \text { Ca/s } & =2.5 \\ \text { Culm Cost } & \$ 2.00 \text { per ton } \\ \text { Ash Disposal Cost } & =\$ 2.00 \text { per ton } \\ \text { Limestone Cost } & =\$ 5.50 \text { per ton }\end{array}$

All flows are in $1 \mathrm{bs} / \mathrm{hr}$

1. Steam Production Factor $=$ (Availability) $\mathbf{x}$ (Load Factor)

$=(.925) \times(1.000)$

$=0.925$

2. Steam Production $=$ (Steam Production Factor) $\times(20,0001 \mathrm{~b} / \mathrm{hr}$ )

$=(0.925) \times(20,000)$

$=18,5001 \mathrm{~b} / \mathrm{hr}$

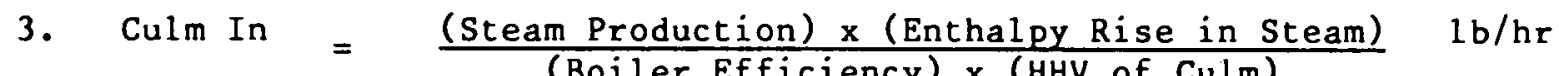

$$
=\frac{(18,500) \times(1171)}{(.735) \times(4041)}=7294 \mathrm{lb} / \mathrm{hr}
$$

4. Limestone In $=($ Culm In $) \times(.04014) * \times\left(\mathrm{C}_{2} / \mathrm{S}\right)$

$=(7294) \times(.04014) \times(2.5)$

$=7321 \mathrm{~b} / \mathrm{hr}$

$$
\begin{aligned}
* 04014 & =\left(\frac{1 \mathrm{bs}}{1 \mathrm{~b} \mathrm{culm}}\right) \times\left(\frac{\frac{1}{1 \mathrm{~b}-\mathrm{mole}}}{32 \mathrm{bs}}\right) \times\left(\frac{1001 \mathrm{~b} \mathrm{CaCO}}{1 \mathrm{~b}-\mathrm{mole} \mathrm{CaCO}_{3}}\right) *\left(\frac{1 \mathrm{~b} \text { limestone }}{1 \mathrm{~b} \mathrm{CaCO}_{3}}\right) \\
& =(.00835) \times\left(\frac{1}{32}\right) \times(100)\left(\frac{1}{.65}\right) \frac{1 \mathrm{~b} \text { limestone }}{1 \mathrm{~b} \text { culm }}
\end{aligned}
$$

5. Ash Out $=(($ Culm In $)+($ Limestone In $) \times 0.7 \div \% 1 \mathrm{~b} / \mathrm{hr}$

$$
\begin{aligned}
& =(7294+732) \times .7 \\
& =56181 \mathrm{~b} / \mathrm{hr}
\end{aligned}
$$

$* 0.7$ is an approximate average ash content of culm plus limestone based upon historical data. 
6. Fixed Cost $=\$ 29.06$ per hour

7. Culm Cost $=($ Culm In $) \times($ Culm Cost $) /(2000)$

$=(1 \mathrm{bs} / \mathrm{hr}) \times(\$ /$ ton $) /(1 \mathrm{bs} /$ tón $)$

$=(7294) \times(2.00) /(2000)$

$=\$ 7.29$ per hour

8. Limestone Cost $=$ (Limestone In) $\times$ (Limestone Cost) $/(2000)$

$=(1 \mathrm{bs} / \mathrm{hr}) \times(\$ /$ ton $) /(1 \mathrm{bs} / \mathrm{ton})$

$=(732) \times(5.50) /(2000)$

$=\$ 2.01$ per hour

9. Ash Cost $=($ Ash Out) $\times($ Ash Disposal Cost) / (2000)

$=(1 \mathrm{bs} / \mathrm{hr}) \times(\$ /$ ton $) /($ lbs $/$ ton $)$

$=(5618) \times(2.00) /(2000)$

$=\$ 5.62$ per hour

10. Variable Cost $=$ (Steam Production) $x .00125+16.92$

$=(18500) \times .00125+16.92$

$=\$ 50.05$ per hour

(See item 14)

11. Total Hourly Cost $=$ (Fixed Cost) $+($ Culm Cost $)+($ Limestone Cost)

+ (Ash Cost) + (Variable Cost)

$=(29.06)+(7.29)+(2.01)+(5.62)+(40.05)$

$=\$ 84.02$ per hour

12. Cost per $10001 \mathrm{~b}$ Steam $=\frac{(\text { Total Hourly Cost })}{\text { (Steam Production } 1 \mathrm{bs} / \mathrm{hr}(f 000)}$

$$
\begin{aligned}
& =\frac{(84.03)(1000)}{(18500)} \\
& =\$ 4.54 / 1000 \cdot 1 \mathrm{~b} \text { steam }
\end{aligned}
$$

13. Total Annual Cost $=($ Total Hourly Cost $) \times(8760 \mathrm{hr} / \mathrm{yr})$

$$
\begin{aligned}
& =(84.03)(8760) \\
& =\$ 7.36,100 \text { per year }
\end{aligned}
$$

14. Variable Cost Equation = (Electrical Cost) + (Water Cost)

$$
\begin{aligned}
& +(\text { Other Variable Cost }) \\
& =\quad(.0006537+.0001929+.0004032) \\
& \times(\text { Steam Production })+(14.32+.5256+2.073) \\
& =.00125 \times \text { (Steam Production })+16.92
\end{aligned}
$$




$$
\text { Sample Calculation - Cogeneration Case }
$$

Input :

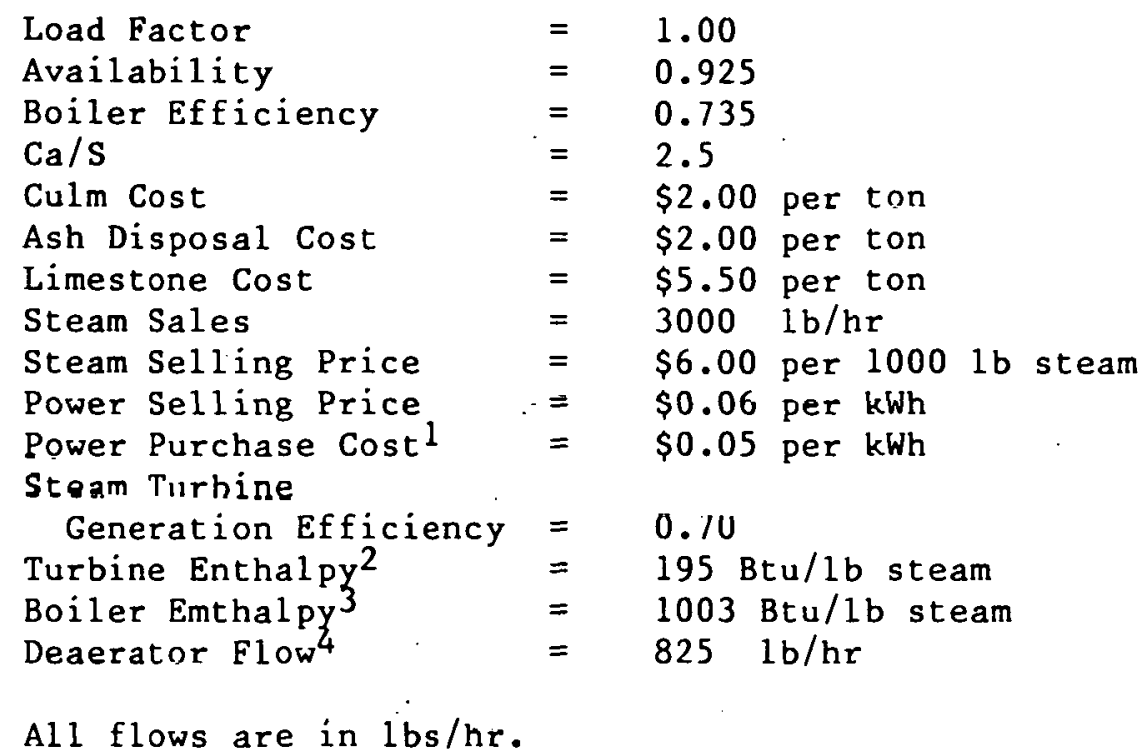

\section{Notes:}

1 Cases of both "net" and "gross" power salcs were considered. In "net" sales, internal power usage was subtracted prior to selling net power at $\$ 0.06$ per kWh. In "gross" sales, total generator output is sold at $\$ 0.06$ per kWh and Incernal power ic repurchased from utility at $\$ 0.05$ per $\mathrm{kWh}$.

2 Turbine Finthalpy - theoretically available enthalpy difference of saturated or superheated steam entering turbiut and enthalpy resulting from isentropic expansion to condenser operating pressure, Btu/Lb.

3 Boiler Enthalpy - enthalpy increase of steam/water from saturated liquid exiting deaerator to saturated or superheated steam leaving boiler, Btu/1b.

4 Deaerator Flow - flow rate of saturated steam necessary to heat makeup waler and condcnoate to reaerator exit conditions (approximately 5 psig, $228^{\circ} \mathrm{F}$ ). Numbers used in calculations are correct for base case flow of $3000 \mathrm{pph}$ steam sales, but are not corrected for other steam sales. 
1. Steam Production $=(1 \mathrm{bs} / \mathrm{hr}-1 \mathrm{bs} / \mathrm{hr}) \times$ Load Factor $\mathbf{x}$ Availability Steam Flow - (Deaerator Flow) x (Load Factor)

$$
\begin{aligned}
& x(\text { Availability) } \\
& =\quad(23400-825) \times(1.00) \times(.925) \\
& =20882
\end{aligned}
$$

2. Culm In $=$ (Steam Flow) $\times$ (Load Factor) $\times$ (Availability)

$x$ (Boiler Enthalpy)

(Boiler Efficiency) $\times$ (Culm HHV)

$=(1 \mathrm{bs} / \mathrm{hr})(\mathrm{Btu} / 1 \mathrm{~b}) /(\mathrm{Btu} / \mathrm{lb})$

$=\frac{(23400) \times(1.00) \times(.925) \times(1003)}{(.735) \times(4041)}$

$=73091 \mathrm{~b} / \mathrm{hr}$

3. Limestone In $=($ Culm In $) \times(.04014) \times(\mathrm{Ca} / \mathrm{s})$

$=(1 \mathrm{bs} / \mathrm{hr})(1 \mathrm{bs} 1$ imestone $/ 1 \mathrm{~b}$ culm)

$=(7309) \times(.04014) \times(2.5)$

$=733 \mathrm{lbs} / \mathrm{hr}$

4. Ash Out $=(($ Culm In $)+($ Limestone In $)) \times 0.7$

$=((7309)+(733)) \times 0.7$

$=56291 \mathrm{bs} / \mathrm{hr}$

5. Turbine Power $=$ ( (Steam Production) - (Steam Sales) $\mathbf{x}$ (Availability)

$x$ (Load Factor)) $x$ (Turbine Enthalpy)

$x$ (Turbine Efficiency) $\div 3413$

$=(1 \mathrm{bs} / \mathrm{hr})(\mathrm{Btu} / 1 \mathrm{~b}) /(\mathrm{Btu} / \mathrm{kW}-\mathrm{hr})$

$=(20882-(3000)(1)(.925) \times(195)(.7) / 3413$

$=724 \mathrm{KW}$

6. Power Usage $=$ Steam Production $\times 0.01866+212.4$

$=(23400) \times$ (Availability) $\times$ (Load Factor) $\times 0.01866$ $+212.4$

$=616 \mathrm{KW}$

7. Power Net $=$ (Turbine Puwer) - (Power Usage)

$=724-616$

$=108 \mathrm{KW}$

Note: For net sales this is multiplied by power sales rate. For gross sales the total turbine power is sold, and the power usage repurchased. 
8. Fixed Cost $=\$ 29.06$ per hour

9. Culm Cost $=($ Culm In $) \times($ Culm Price $) / 2000$

$=(1 \mathrm{bs} / \mathrm{hr}) \times(\$ /$ ton $) /(1 \mathrm{bs} /$ ton $)$

$=(7309) \times(2.00) / 2000$

$=\$ 7.31$ per hour

10. Limestone Cost $=$ (Limestone In) $x$ (Limestone Price) $/ 2000$

$=(1 \mathrm{bs} / \mathrm{hr}) \times(\$ /$ ton $) /(1 \mathrm{bs} / \mathrm{ton})$

$=733 \times 5.50 / 2000$

$=\$ 2.02$ per hour

11. Ash Disposal Cost $=$ (Ash Out) $\times($ Disposal Price) $/ 2000$

$=(1 \mathrm{bs} / \mathrm{hr}) \times(\$ / \mathrm{ton}) /(1 \mathrm{bs} / \mathrm{ton})$

$=5629 \times 2.00 / 2000$

$=\$ 5.63$ per hour

12. Variable Cost $=$ Steam Production $\times 0.000427+2.337$

$=$ (Steam Flow) $\times$ (Load Factor) $\times$ (Availability) $\mathrm{x} .000427+2.337$

$=(23400) \times(1.00) \times(.925) \times .000427+2.337$

$=\$ 11.58$

13. Total Operating Cost $=($ Fixed Cost $)+($ Culm Cost $)+($ Limestone Cost)

+ (Ash Disposal Cost) + Variable Cost) + (KW Ueed) $\times$, $05 \%$

$-29.06+7.31+2.02+11.26+11.58+616 \times .05$

$=\$ 86.40$ per hour

*Gross Sales Case

14. Steam Revenue $=$ (Steam Sales) $\times$ (Load Factor) $\times$ (Availability)

$$
=(3000) \times(1.0) \times(.925) \times(6.00) / 1000
$$

$=\$ 16.65$ per hour

15. Power Revenue* $=$ (KW Produced) $\times$ (Power Price)

$=724 \times .06$

$=\$ 43.44 / \mathrm{hr}$

*Gross Power Sales Case

16. Total Revenue $=$ (Steam Revenue) + (Power Revenue)

$=16.65+43.44$

$=\$ 60.09$ per hour 
17. Net Revenue $=$ (Total Revenue) - (Total Cost)

$=(60.09)-(86.40)$

$=-\$ 26.31$ per hour

18. Annual Revenue $=$ (Net Revenue) $\times 8760$

$=-\$ 26.31 \times 8760$

$=-\$ 230,500$ 
APPENDIX C-1

SHAMOKIN OPERATING COST SUMMARY 


\section{Summary Nomenclature}

Abbreviation

Nomenclature

Load Fact

Load Factor

Availability

Availability

Efficien

Efficiency

Ash Disp

Ash Disposal

SPF

Steam Production Factor

STM Prod

Steam Production

Disp Cost

Disposal Cost

Varbl Cost

Variable Cost

Note: Column numbers refer to Case Numbers. 


\begin{tabular}{|c|c|c|c|c|c|c|c|c|c|c|}
\hline LOADE FÄL & ‥ 1 & 6.450 & 9. $\begin{array}{c}5 \\
56\end{array}$ & 5. 54 & Q.75 & 日. 5 & 9.58 & ․ 78 & 回. & 6. 80 \\
\hline AUA I LAELT T' & 6. 756 & Q. 5 & ‥75 & 5.756 & $9.7=0$ & 9.756 & 日. 756 & 目. 75 & Q.7. 70 & 9.75 \\
\hline EFFILIEH & 9.75 & 0.75 & 0.735 & 9.75 & 9.75 & 0.735 & 0.735 & Q 13.5 & 0.755 & 0.75 \\
\hline$A B$ & 4.810 & 4. & 4. 01010 & 1016 & 4. 5150 & 4. 브은 & 4. 01510 & 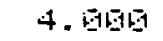 & 4. Enteis & \\
\hline EILAM EOST & G. Et:15 & B. E1510 & 6. 516 & 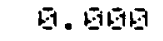 & 6. 6150 & E. E1ㅛ & Q. & 6. E1510 & 日. 0100 & E. \\
\hline DISP & 6. 015 & 000 & 6. 01019 & 可. 0010 & Q. & 6. ․ㅛㅇㅛ & Q. E. EN & 6. 6015 & 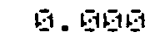 & Q. 000 \\
\hline & 90 & . 5400 & .5610 & & & & & 50 & .560 & \\
\hline$F \cdot F$ & 0.694 & 5013 & .338 & .375 & 0.525 & 日. 4.5. & 日. $4: 3: 3$ & 6.525 & 0.505 & \\
\hline STM PFQO & 12375 & ED101. & 5750. & 7500. & 10580. & 90150. & $9>59$. & 105010. & 1125. & 12010 \\
\hline E!ILA IH & 5470. & 230. & 201. & 2957 & 4146. & $35,4:$ & 5844 & 4148 & 443.5. & 4731 \\
\hline STIUHE IH & :39. & PEQ & 427 & 475. & 505. & 575. & $\dot{\theta 17}$. & $E .5$. & 712. & 78 \\
\hline HEH DIIT & 4444. & 1922. & $21 \mathrm{E} 2$. & 2462 & TIET. & $283 \pi$ & $312=$ & SEE. & उGET. & SES \\
\hline IYED EIST & 29.96 & 29.65 & 29.65 & 29.65 & 20.516 & 29.51 & 29.60 & 29.60 & 20.6 & 29 . \\
\hline HUM EIET & 国. & 5. 1918 & [1. 106 & 日. & 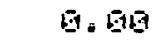 & 1. 109 & 国目田 & E. E1 & - 1.5 & 6. 80 \\
\hline E E.II:ST & 2.42 & 1.94 & 1.13 & 1.31 & $1 .: 3$ & $1.5 \%$ & 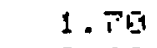 & $1:-\overline{1}$ & 1.5 & \\
\hline 100OT & 15. 519 & 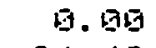 & E. 515 & 51.815 & 0.513 & 5.51 & Q1.010 & Q. 810 & E. E16 & \\
\hline UAFEL EOST & 54.20 & 24.42 & 25.36 & 25.56 & 36.65 & 28.17 & 29.11 & 36.65 & 35.98 & $\Xi 1$. \\
\hline & & $=2$ & & & & & & & E19 & \\
\hline & 30 & 9. & & 5. & & & $4 \sqrt{1}$ & 5.5 & 5.511 & \\
\hline e & 95 & PESG & 961 & 49587 & 5.5792 & 5150 & 524415 & 59572 & 43128 & 55 \\
\hline
\end{tabular}

BHAMOKIH BFEFATIHI DOST BUMMAF'Y

\begin{tabular}{|c|c|c|c|c|c|c|c|c|c|c|}
\hline & 11 & 2 & 1.5 & 14 & $1: 5$ & 15 & 17 & $1: 3$ & 19 & -1 \\
\hline LDAO FAET & 0.050 & ‥ 906 & 0.9519 & 0.925 & 0.95 & ㅁ. & 6.925 & 0.925 & 6.925 & 51.92 \\
\hline WHA ILAELT' & 9.756 & ‥1. 756 & 6. 756 & E1.75 75 & ‥75 & 1. 750 & 5.750 & 6. 750 & 9.75 & \\
\hline FFIEIEH & 0.735 & 0.755 & 1.7.5 & 9.80 & Q. & 6.78 & 5 & Q. 3019 & B. 735 & \\
\hline$A$ & 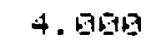 & 4.6100 & 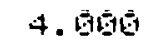 & 4.6190 & 4.81509 & 4. .1515 & 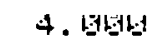 & 4. E1516 & 9.009 & \\
\hline EILILM EIET & 1. 브는 & 1. 0100 & 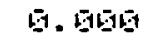 & 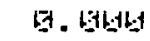 & 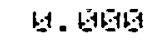 & 6. 0190 & ‥ 9190 & 9. 010 & 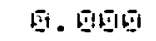 & \\
\hline HEH $\triangle I S F$ & Q. 5. 5150 & 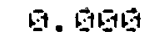 & 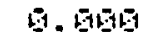 & 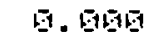 & 日. 国是且 & 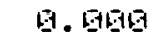 & 1. 1010 & 6. E10 & 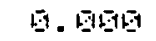 & 5. \\
\hline I HESTER & 5.509 & 50.9 & 56 & Q6101 & 5.5615 & 5.5 & 5.515 & 5.5196 & 0015 & \\
\hline$E F F$ & 0.08 & 6.875 & 9.715 & $\leqslant .644$ & 壮 . & 1. 54 & ㅂ. 54 & Q.5.54 & 9.84 & 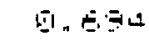 \\
\hline STM FFIOL & 12750. & 135010 & 14250 & 13575. & 13075 & 13075 & 13575 & 13075 & 13075 & $1=0$ \\
\hline ELILA IH & 51927. & 5222 & 5013. & E7l. & 6135 & 574 & $5 \sin 1$ & 562 & :479. & 54 \\
\hline TIDVE IHS & Bat? & : Fis. & 가으. & 1975. & 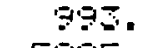 & 叫 & 舁1. & Bas. & 且. & \\
\hline SH BUIT & 46134. & 4.24 & 4.564 & 5444. & 5625 & 4586. & 455. & 4008. & 2039 & \\
\hline I:BEO LODST & 29.60 & 29.06 & 29.60 & 29.6 & 29.68 & 20.65 & 29.65 & 20.65 & 29.65 & $\because$ \\
\hline EILLM EODETT & 1. & Q. 60 & 䭪早 & 5.515 & - 6.69 & E. E1 & 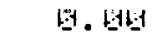 & 1. 801 & 国. 10 & \\
\hline STOHA EOST & ร. & ב. & $2.4: 3$ & 2 & דידיה & $I: 5.44$ & 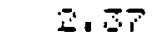 & 2.2 & 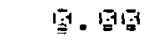 & \\
\hline DISF DOST & E. & B. 101 & 6. 610 & 0.50 & E. EDE & 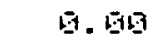 & E. E. E15 & 19. 010 & 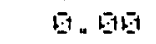 & \\
\hline UAFELL BE:ET & $2.8 B$ & 5.801 & 4.73 & 34.25 & 34.26 & 34.25 & 34.25 & 54.28 & 34.25 & 54 \\
\hline \$ $\mathrm{HF}$ & $\therefore 4.14$ & 6.21 & E.E. & E. 20 & 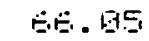 & 8.58 & E.5. & 8.54 & 5.52 & \\
\hline$\Rightarrow 10+16$ & 5.06 & 4.806 & 4.51 & 4.778 & 4.781 & 4.747 & $4.7=4$ & 4.724 & 4. 54 & 4. \\
\hline$\$ y^{\prime} F$ & 51546 & 071197 & 60505 & 50.5 & $7=42$ & 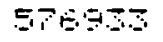 & $845=$ & $59+150$ & $E=4718$ & $\cdots$ \\
\hline
\end{tabular}


SHAMDKIH DFEFHTIHG DOST SUMMAFY'

\begin{tabular}{|c|c|c|c|c|c|c|c|c|c|c|}
\hline & 21 & 22 & 25 & 24 & 25 & 26 & 27 & 28 & 29 & 50 \\
\hline LGAD FAET & 1.925 & 0.925 & 0.925 & 0.925 & ‥ 925 & 0.925 & 5.925 & $0.92=$ & 6. 925 & 1. 92 \\
\hline HUAILAELTY & 9.750 & 9.750 & 0.750 & 0.750 & 0.750 & 0.750 & Q.7. & 0.756. & 0.750 & 9.756 \\
\hline EFFICIEH & 0.75 & 0.735 & 1.7.55 & 0.755 & 0.735 & 0.735 & 5.735 & ㅌ.735 & E. & \\
\hline DASO & 2.6010 & 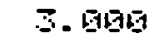 & 4. 0100 & 5.000 & 4.5615 & 4. E150 & 4. 5000 & 4. 0190 & 4.000 & 4. \\
\hline ELLLM EOST & 6. 8019 & E. 5150 & 0. 809 & 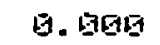 & 0.000 & Q. 5090 & 0. 0100 & 0. 000 & ‥ 매트 & 日. 5 \\
\hline ASH DISP & 9106 & ‥ 61569 & 9. 1896 & 5. 5150 & 0. 000 & Q. QABG & Q. 8160 & 31 & 日. Sug & $\theta$. \\
\hline LIMESTONE & 010 & 5.509 & 5.560 & 5.5130 & 0. 619 & 2.6016 & 4. 505 & 5 & 8.00010 & \\
\hline$S F F$ & 0.694 & Q. 694 & 5.694 & B. 694 & 0.694 & 9.694 & 0.594 & 9.694 & Q. 594 & . \\
\hline STM FFIOL & 15075. & 13075 & 13875. & 1.895 & 13875. & 13875. & 13075. & $18 \Xi 75$ & 15075 & 13 \\
\hline EILLM IH & 5479. & 5476 & 5470. & 5궁. & 5479. & 5470. & 5475. & $547 \mathrm{~B}$. & 5475. & 547 \\
\hline STIDHE IH. & 439 & 659 & 878 & 1898. & 373. & 57: & s7e. & 87 & $8 \%$ & 8 \\
\hline AEH OUIT & 4137. & 4296 & 4444 & 4593. & 4444. & 4444 & 4444. & 4444. & 4444. & 44 \\
\hline$=$ IMED LOIST & 29.96 & 29.96 & 29.615 & 29.196 & 29.65 & 29.56 & 29.00 & 29.190 & 29.61 & 29 \\
\hline BULM BOST & 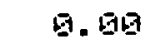 & E. B日 & 0.85 & ㅂ. 518 & 19. 615 & Q. 00 & 0. 100 & ‥ & 日. & \\
\hline STINE CIIST & 1.21 & 1.31 & 2.42 & 3.52 & Q. 9 & B. 38 & 1.PE & 2. & 3.51 & \\
\hline DISF DOST & 0.60 & Q. 18 & 0.65 & 日. B日 & E. EQ & Q. 519 & 0.60 & 19. 60 & 日. 60 & \\
\hline 1!AFEL $Q \mathrm{OUTT}$ & 34.26 & 34.26 & 34.26 & 34.26 & 54.26 & 54.26 & 34.26 & 34. & 34.25 & 54 \\
\hline$\$ \mathrm{HF}$ & 64.53 & 65.14 & 65.74 & 34 & 63.32 & 64.20 & & & & \\
\hline$\$ 1000$ & 4.551 & 4.694 & 4.738 & 4.731 & 4.564 & 4.627 & $\exists E$ & & 4.8 & \\
\hline F YR & 95 & 61585 & 75075 & $5: 1154$ & 554716 & 562410 & 570 & 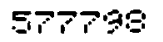 & 05492 & 593 \\
\hline
\end{tabular}

BHAMDKIN DFEFATIHIS DOST SUMMAF'Y

\begin{tabular}{|c|c|c|c|c|c|c|c|c|c|c|}
\hline & 31 & 32 & 33 & 34 & 35 & $S E$ & 37 & 3 & 59 & 49 \\
\hline DAAC FAET & 0.925 & 日. 925 & 0.925 & 1.925 & 19.925 & 1.925 & 1. 3010 & 0.350 & 日. 409 & 0.450 \\
\hline AUAILAELLT' & 9.756 & 9.756 & 0.759 & 5.756 & Q. 755 & 1. 5015 & 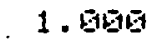 & 1. 601 & 1. . 1016 & 1. BED \\
\hline FFIEIEH & 9.735 & 0.755 & 0.735 & 9.755 & 田。 & 9. 735 & 9.735 & 9.735 & 0.735 & 0.785 \\
\hline$A B$ & 4.650 & 4. 8019 & 4.5190 & 4.9619 & 4.0100 & 2.590 & 2.5010 & 2. 5615 & 2.540 & 2.500 \\
\hline EULM EOEST & 5. 0019 & 1. 0100 & 0.900 & Q. & Q. 5000 & 2. Ene & 2.0019 & 2.0100 & 2.0196 & 2.506 \\
\hline$A B H \quad D I S F$ & 5. E15日 & 01615 & 5. 919 & B. B日⿴囗十 & B. E196 & 2.01001 & 2.018 & Ge日E & 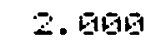 & 2.005 \\
\hline IMESTTHE & 12.960 & 14.61515 & 18.960 & 15.5150 & 20. & 5.510 & 5610 & 5 & 4 & \\
\hline$B F F$ & $0.6 \% 4$ & 13. 694 & 1.594 & 6.694 & 8.644 & 3.920 & Q. 3615 & 9. 5510 & 国. 40 & 5.45 \\
\hline TM FFOOO & 13075 & 13075 & 13075 & 13375. & $13: 75$ & 185 즌. & BDE1․ & PE1615. & E6010. & 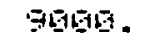 \\
\hline ULUM IH & 5476. & 5479. & 5475. & 5.47․ㅡ. & 54701 & 7294 & 23ES & 27ธ日. & 3154 & 5045 \\
\hline ETERHE IH & 875. & Brs. & B. & 373 & :373. & 732 & 237 & 277 & 317 & 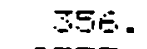 \\
\hline AEH DITT & 4444 & 4444 & 4444 & 4444 . & 4444 & SE1:. & 1322 & 2125. & 2429 & 2735 \\
\hline TKED EDST & 29.86 & 29.65 & 29.56 & 29.58 & 29.16 & 29.05 & 29.06 & 29.15 & 29.56 & 29.56 \\
\hline :LLM EIDST & E. 615 & 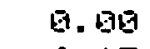 & 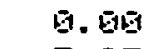 & 19. 18 & D. 16 & 7.29 & 2.37 & 2.78 & 5.15 & 3.55 \\
\hline STIHE EQBT & 5.27 & - 15 & 7.93 & 7.99 & 5,78 & 2.01 & 9.55 & ‥75 & 5. 87 & 1.93 \\
\hline OISF DODST & 可. & Q. 0.0 & 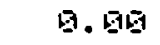 & Q. 510 & 1. 101 & 5.62 & 1.32 & 2.13 & 2.43 & 2.73 \\
\hline UAFEL DOLT & 34.26 & 4 & 4.25 & 34.20 & 34.25 & 40.55 & 24.42 & 25.67 & 26.92 & 29.17 \\
\hline Five & 58 & 9.47 & 1 & 71.23 & & & & & & 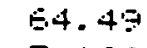 \\
\hline 160 & 44 & 5.1 & B & 5.134 & 5.197 & & 20 & & P. & 7.156 \\
\hline "R. & 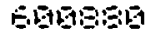 & 18594 & $E 269$ & 390.5 & 05165 & $P 3$ & $516:$ & & $: 1$ & 18 \\
\hline
\end{tabular}




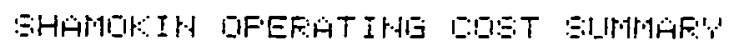

\begin{tabular}{|c|c|c|c|c|c|c|c|c|c|c|}
\hline & 41 & 42 & 45 & 44 & 45 & 45 & 47 & $4: 3$ & 49 & 501 \\
\hline L.QAAC & 9.5010 & 0.5 .50 & 5. 56 & ㅂ. 5.5 & Q. 7 P & 5.75 & - & 5.950 & 9.9610 & $9,5 e 5$ \\
\hline $\begin{array}{l}\text { AUAILAELT } \\
\text { EFFIIIIEHT }\end{array}$ & $\frac{1}{9} \cdot 7+5$ & 1. E1016 & 1.6196 & 1.9019 & 1.096 & $\frac{1}{10}$. 10日 & 1. & 1. & $1 \cdot 0$ & 1. \\
\hline$\therefore A B$ & 2.569 & 2.560 & 2.500 & 2.560 & 2.560 & 2.56 & 2.56 & 2.50 & 2.56 & 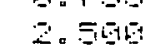 \\
\hline BIULH BDET & 2.0015 & 2.010101 & 2.6109 & 2.010 & 2. 6100 & 2 . D10日月 & 2. DETE & 2.060 & 2.0101 & 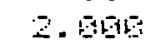 \\
\hline HEH OISF & 2. 01615 & 2.5100 & 2.010 & 2.0150 & 2. 0101 & BEAT & 2.0016 & 2.1 & 40 & \\
\hline LIHESTDHE & 5.580 & 5.561 & 5.560 & 509 & 890 & 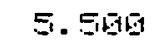 & 5001 & 15 & 45 & $E$. \\
\hline$E F \cdot F$ & 5.560 & 日. 5.55 & E. E. E15 & 0.58 & Q.7日日 & 9.750 & 国. & G. B5.5 & E. 961 & ㅍ. \\
\hline STM FFIOS & 10101078. & 11 E1010. & $12010+10$. & 1.트므. & 145515. & 15616169. & 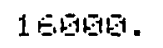 & 17050. & 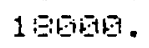 & 1900 \\
\hline EILU & 3943. & $4 \Omega 8$ & 451 & 5125. & 5.526 & 5914. & ESEE. & 5792. & 7097. & 745 \\
\hline ETOHE IH & . & 4.5 & 475. & 514. & 5.5 & 59.8. & B.S. & E. & 712 & 75 \\
\hline AESH DIIT & 36157 & 534. & 3644 . & 734:5. & 4251. & 4555 & 4059. & 5152. & 5456. & $5 \%$ \\
\hline F.MED EOST & 29.96 & 29.15 & 29.50 & 29.18 & 29.96 & 29.65 & 29.6 & 29.15 & 29.8 & 9. \\
\hline EILM EIST & $\therefore .94$ & 4.54 & 4.75 & 5.13 & 5.52 & 5 & $\because .51$ & 5.79 & P.11 & $P$. \\
\hline ETOHE GOET & 1. & $1.2 \mathrm{~b}$ & 1.31 & 1.41 & 1. & 1.05 & 1.74 & 1 . 1 . & 1.96 & 3. \\
\hline DISt & 5.54 & $\Xi$ & 5.54 & 3.95 & 4.25 & 4. & 4.85 & 5.15 & 5.47 & 5. \\
\hline WAFELL EOIST & 29.42 & 78.67 & 31.92 & 39.17 & 34.42 & 35 & 36.92 & 30.17 & 59.42 & 45. \\
\hline t) HF: & ت. & 68.86 & 79.6 & 72 & & & 59 & 80.94 & 85 & \\
\hline$F 15 E$ & 8.655 & 6.237 & 5.8018 & 5.594 & 5.3 & 5.12 & 4.95 & 4.781 & 4.511 & 4. \\
\hline$\$, \mathrm{~V}^{\prime} \mathrm{F}$ & 58295.5 & 6010972 & 19989 & 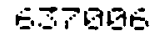 & 65 & 67 & $591 \mathrm{BST}$ & 756964 & マ๐ด 1 & 75 \\
\hline
\end{tabular}

SHAMOKIH DAFEFATIHG DOST BUMMMAY'

\begin{tabular}{|c|c|c|c|c|c|c|c|c|c|c|}
\hline$\because F$ & $\begin{array}{c}51 \\
925\end{array}$ & 52 & $5=$ & $\begin{array}{l}54 \\
975\end{array}$ & $\begin{array}{l}5: 5 \\
3 \rightarrow=\end{array}$ & 56 & 57 & 5 & & $\because 2$ \\
\hline AUA I LAEL T & $\begin{array}{l}1.925 \\
1.0650\end{array}$ & $\begin{array}{l}3.925 \\
1.0190\end{array}$ & $\begin{array}{l}1.925 \\
1.9010\end{array}$ & $\begin{array}{l}\text { 1. } 925 \\
1.61010\end{array}$ & $\begin{array}{l}9.925 \\
1.01516\end{array}$ & $\begin{array}{l}0.925 \\
1.0610\end{array}$ & $\begin{array}{l}0.925 \\
1.6196\end{array}$ & 1. 625 & $\begin{array}{l}0.925 \\
1.900\end{array}$ & $\begin{array}{l}1.920 \\
1.0610\end{array}$ \\
\hline EFFI:IEF & 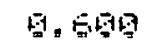 & 9.56 & 日. 78 Q & E. 75 & Q. 80 & 5.75 & Q1. 7.5 & 5.75 & 0.75 & 9.7 \\
\hline EA S & 60 & 2.500 & 2.5616 & 2.560 & 2.51019 & 国. & 1. Q15 & 2.0115 & $\therefore 5015$ & 4.1 \\
\hline EULLA EOST & 2.6160 & 2.816 & 2. 600 & 2. 015 & 10 & DISta & 115:4t:-1 & 19. & & \\
\hline SH OISF & 2.01619 & 2.0015 & 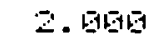 & 2.6160 & 2.0010 & 2.0150 & 2 . E100 & 2.019 & 2.615 & \\
\hline IMESTGHE & 5.5619 & 5.5615 & 5.56 & 5.5616 & 5.5015 & 5.5610 & 5.5515 & 5670 & 5.5810 & \\
\hline EF'F & 0.925 & 10.9 & 5.925 & E.925 & 5.925 & 5.9 & B. 92 & 国.95 & 5.95 & \\
\hline STM FPOOL & $1: 50.010$. & 185 1919. & $1:=5619$. & 19510. & $1: 5601$. & $1: 5010$. & $1: 560$. & $1 \Xi$ 드는. & $1: 5$ inge. & 185 \\
\hline EILILI IH & :95. & $924:$ & 785. & $714 \Omega$. & E7. & 7294 & 294. & 7294. & 7294. & \\
\hline STDHNE IH & $\$ 97$ & 928. & PE. & 717. & 572. & B. & 293. & EEs. & $\Xi B$ & 11 \\
\hline HEH IIUT & $6: 82$ & 655 & 5899. & 55610. & 5162. & $510 \%$ & 5.11 & 515. & 520. & 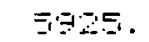 \\
\hline FIYED GDST & 29.68 & 29.65 & 29.61 & 29.96 & 29.65 & 29. & 20. & $2=8$ & 20.8 & 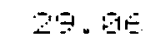 \\
\hline ELLAM EOET & 5.95 & 3.25 & 7.86 & 7.15 & E.7日 & 7.29 & 7.29 & 7.29 & 7.27 & \\
\hline 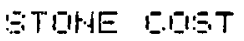 & 2.47 & & 2.11 & $1 .:$ & 1.85 & 9. .501 & E. 011 & 1. & $2: 42$ & \\
\hline [ISF DOET & ย. E: & $E .5$ & 5.96 & 5.5 & 5. & 5.11 & 5.51 & & 5.72 & \\
\hline WAEELL EOST & 45.55 & 46.1 & 46.55 & 45. & 46. & 45.615 & 45.55 & 46.5 & 451.65 & 45 \\
\hline F $\mathrm{HF}$ & 87.5 & $: 5$ & $: 4.78$ & 85 & 82.82 & & 5.51 & 5 & 84.5 & \\
\hline 51 1 & 1.724 & $4.5: 5$ & $4.5: 2$ & 4.50 & 4.477 & 4.450 & 4.48 .5 & 4.515 & 4.569 & 4. \\
\hline F & $7 E 515$ & 5.9196 & 7425 & 7.5484 & 72579 & 713979 & 72207 & 731575 & 74052 & 7 \\
\hline
\end{tabular}


SHAMOKIH DFEFATIHE DIET EIMNMAF'

\begin{tabular}{|c|c|c|c|c|c|c|c|c|c|c|}
\hline & & $E 2$ & 85 & 6.4 & 65 & Es & 87 & $\begin{array}{l}60 \\
920\end{array}$ & $\begin{array}{l}69 \\
925\end{array}$ & $\begin{array}{l}70 \\
98\end{array}$ \\
\hline & 0.925 & 6. 925 & 9.925 & 9. 925 & 9.925 & 0.925 & 25 & 0.925 & 9.925 & 0.920 \\
\hline WAILAELT'W & $1 \cdot 0100$ & 1.01010 & $1 \cdot \operatorname{sing}$ & 1.810 & 1.0150 & 1.51016 & 1 - EDE & 1.513 & 1.010 & $\frac{1}{0}=-7=$ \\
\hline EAR & 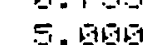 & 2.56 & 2.50 & 2.5190 & 2.50 & 2.500 & 2.5010 & 2.5101 & 2.500 & 2.50 \\
\hline DIILM GDET & 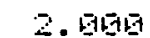 & B. 5010 & 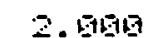 & 4.51019 & E. E19日9 & 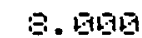 & 1日. 8150 & 12. 묘요 & 14.01010 & $1 E$ \\
\hline$A B H$ QISP & 2.01919 & 2.0010 & 2. 64019 & 2. Etats & 2. ELata & 2.0190 & 2. 8100 & 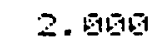 & 2.6100 & 2.6 \\
\hline IMESTOHE & 5.560 & 5.5010 & 5.500 & 5.5196 & 5.515 & 5.560 & 5.560 & 5.580 & 5.560 & 5.5 \\
\hline$F F$ & 0.925 & 19.92 & & 0.925 & 5.925 & 1.925 & 9.925 & 0.925 & 19.925 & \\
\hline STM FPOD & 185010. & 10506 & 18560. & 19580. & 105010 & 1858. & 185010 & $1: 5010$. & 18500. & $1: 5$ \\
\hline BULAM IH & 7294 & 7294. & 7294. & 7294 & 7294 & 7294. & 7294 & 7294 & 7294. & 72 \\
\hline STIHNE IN & 1454. & 732 & 732 & 732 & 732 & $P 32$. & 732 & 732 & 722 & 7 \\
\hline AEH DOUT & S13日. & 5615. & 513. & 5818. & $5 \leqslant 15$ & 518. & 5615. & 501 & 5618. & 58 \\
\hline FISED DOST & 29.56 & 29 & 29.65 & 29.615 & 29.56 & 29 & ES & 29 & & \\
\hline DULM EOST & 7.29 & 6. & 7.29 & 14.59 & 21.88 & 29.19 & 36.47 & 4.78 & 51.50 & 5. \\
\hline STIITE RoST & 4.5 .5 & & 2 & 2. & 2. 11 & 2.91 & 2. 11 & 2. & 2.01 & \\
\hline DISEF GIDST & E. 13 & 5. & 5.62 & 5.52 & 5.82 & 5.62 & 5.62 & & 5.62 & \\
\hline UAFEL OOST & 40.95 & 49 & 49. & 46.0 .5 & 4 4. ES & 48.95 & 40.5 & 4 & 46.65 & 45 \\
\hline 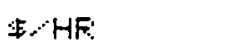 & 86.5 & & & 31. & 99.62 & 1.5 & 113.25 & 12 & 127 & 13 \\
\hline & 4.579 & 4. & 4. & 4. & 1 & 5. & 6.119 & 5 & $E .5$ & \\
\hline 5 & 59226 & 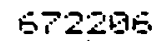 & - & & & B & & & & $1: 3$ \\
\hline
\end{tabular}

SHAMOKIH DFEFATIHI DOST BUMMARY

\begin{tabular}{|c|c|c|c|c|c|c|c|c|c|c|}
\hline & 71 & 72 & 73 & 74 & 75 & $7 E$ & 78 & $\begin{array}{c}78 \\
025\end{array}$ & $\begin{array}{c}79 \\
925\end{array}$ & \\
\hline LDAC FAET & 0.925 & 0.925 & 1.925 & 9.925 & ‥925 & 1. 925 & 回. 925 & 1. 925 & 5.925 & E. \\
\hline AUAILABLTU & 1.800 & 1. 제요 & 1 : 1961日 & 1. 5196 & 1. . 1010 & 1. 51010 & 1. & 1.0 & 100 & 1. - 101 \\
\hline EFFIEIEH & 1.735 & 19.75 & 0.735 & Q.7.55 & B. 7.55 & B. 735 & 5.735 & 0.735 & 0.735 & 9.7 \\
\hline BAS & 2.560 & 2.569 & 2.51010 & 2. 5日a & 2.500 & 58015 & 2.5010 & 2.51615 & 2.5151 & E1: \\
\hline EILAN BOSET & 13.5019 & 20. 日50 & 2.01019 & 2. 19016 & 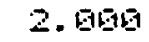 & 2.61610 & 2.616 & 2.9010 & 2.01519 & \\
\hline$A B H$ DISF & 2. E100 & 2.0150 & 1. 0196 & 2.0190 & 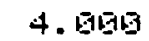 & E. D1510 & B. 01018 & 15.8015 & 9 & \\
\hline LIMESTOK. & 5.5014 & 5.5851 & 5.560 & 9 & .515 & EES & 5.5010 & 5.569 & 19 & \\
\hline$B F F$ & 0.925 & 5.925 & 19.925 & 6.925 & 5.925 & 0.925 & 0.925 & 0.925 & 0.925 & \\
\hline STM F'FIOC & $1: 5610$. & 13 .5日. & 180.30. & 180.018. & 185010. & 185610. & 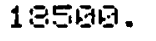 & 185649 & 185001 & 185 \\
\hline EILM IH & 7294. & $\begin{array}{l}794 . \\
732 .\end{array}$ & $\begin{array}{r}7294 . \\
732 .\end{array}$ & $\begin{array}{l}P 294 . \\
732 .\end{array}$ & $\begin{array}{l}P 294 . \\
P 32 .\end{array}$ & $\begin{array}{r}234 . \\
732 .\end{array}$ & 7294 & 7294 & $72=4$ & 82 \\
\hline $\begin{array}{l}\text { SHDPAE ITH } \\
\text { AESH OULTT }\end{array}$ & $=18$. & Sis. & 510. & 561 & 51 & $5: 13$. & 518. & $581 \Xi$ & 515 & 51 \\
\hline FIYED DUET & 29.015 & 29.65 & 29.06 & 29. & 29. & 29. & 29.60 & 29. & 29. & \\
\hline GLLW EOETT & 5.5 .64 & 72.94 & 7.29 & 7.29 & 7. & 7.29 & 7.29 & 7.29 & 7.27 & \\
\hline STOHE EOET & 2.01 & 2.01 & 91 & & & 2. & 2.01 & 2.01 & 5.516 & \\
\hline DISF & 5.62 & 5.62 & B. 109 & 5 & 11. & 15. & 22.47 & 28 & 52 & \\
\hline WHFEL IE & 40.95 & 40.09 & 48.09 & & & & 48.645 & 45 & & \\
\hline$\neq \mathrm{HF}$ & 142.38 & 67 & $7:$ & & & & 1 [1음 & 15 & & \\
\hline$\neq 1$ & & 8.590 & 4.230 & & & & 5. & & & \\
\hline $\pm y^{\prime}$ & & 11140 & $\cdots$ & & 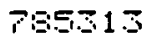 & -7 & 803 & & $F$ & \\
\hline
\end{tabular}




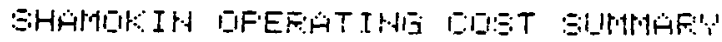

\begin{tabular}{|c|c|c|c|c|c|c|c|c|c|c|}
\hline & 81 & $E 2$ & 95 & $\because 4$ & $: 5$ & 80 & $\theta$ & 80 & 80 & 5 \\
\hline LQAD FAET & $\$ .925$ & Q. 925 & 5.925 & 0.925 & 9.92 & 9.95 & ‥ 525 & 5.925 & - 90 & 0.010 \\
\hline AUAILAELTY & 1.0016 & 1. 610 & 1. 61010 & 1. & 1. BDE & 1. ODE & 1. Engen & 1. DED & 1. 601 & - $\cos \theta$ \\
\hline EFF IEIEH & ㅁ. 755 & 9.75 & G.755 & 9.755 & 9.755 & 0.75 & 8.75 & 8.755 & 0.755 & Q. 010 \\
\hline$E A B$ & 2.506 & 2.5150 & 2.5616 & 2.5010 & 2.500 & 2. 5.515 & 2.515 & 2.5160 & 2.51501 & 6. 0150 \\
\hline ELILH DOST & 2.01016 & 2.0106 & 2.0100 & 2. 비뇨 & 2.6515 & 2. E150 & 2.01010 & 2.600 & 2.000 & Q \\
\hline AEH DISF & 2. E15日E & 2.61616 & 2.81019 & 2.01019 & 2.6016 & 2. 1016 & 2.8016 & 2.816101 & 2.5156 & Q1. B150 \\
\hline LIMESTTRISA & 4.91019 & E. 51001 & 5.809 & 1E. ENE & 12.8150 & 14.01516 & $1 \in$ E E 1010 & 18. 100 & 20.016 & 日. \\
\hline$F^{\prime} F$ & 0.925 & 0.925 & 0.925 & 4.925 & 0.925 & 0.925 & ㅇ. 925 & 6.925 & 9.925 & D. E10 \\
\hline ETM FEIDL & $1 B E E-15$. & $1: 5016$. & $1: 5619$. & 1 :5:50日. & 18 :5E1. & $1: 5015$. & $1: E: 10$. & $1: 56015$. & 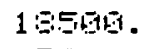 & 8. \\
\hline GULW IH & 7294 & $72=4$. & 7294 & 794 & 7294 & 7294. & 7234. & $72=4$. & 724. & 8. \\
\hline $\begin{array}{l}\text { STEHHE IH } \\
\text { ASH OUT }\end{array}$ & $\begin{array}{r}732 . \\
51513 .\end{array}$ & 510 & $\begin{aligned} 732 . \\
515 .\end{aligned}$ & $51=$ & $\begin{array}{r}782 . \\
518 .\end{array}$ & $\begin{array}{l}732 . \\
518 .\end{array}$ & $=8$ & $=72$ & 7520 & 星。 \\
\hline IYEL EDET & 2 & 29.60 & 29.65 & 29.96 & 29.69 & 23.01 & $2 \exists .60$ & 29.96 & 20 & E. E \\
\hline GUMM EDET & 7.23 & 7.2 & 7.29 & 7.79 & P.23 & 7.23 & 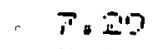 & T. & 7.23 & D. 84 \\
\hline OTUHHE CODST & 1.40 & 2. & 2.9 & 3. Б6 & 4.39 & 5.12 & 5.86 & 5.59 & 7.32 & E. 8 \\
\hline DISF $\quad$ LOST & 5.52 & & $E 2$ & 5.52 & 5.52 & 5.52 & 5.8 & 5.82 & 5.82 & Q. 016 \\
\hline AFEEL EIIST & 45.515 & 40.1 & 45.195 & 419.95 & $4 \overline{19} .5$ & 46.65 & 49.85 & 48.69 & $46-015$ & 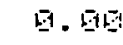 \\
\hline & $83.4: 3$ & 84 & $\because 4$ & B5.6B & 85 & $\theta$. & 87.87 & $8: E .6$ & 89.34 & E. 5 \\
\hline & 4.512 & 4.5 & 4.592 & 4.631 & 4.671 & 4.715 & 4.756 & 4.75 & 4.50 & 6. 610 \\
\hline DVF & 731296 & 737702 & 744114 & 756526 & 750937 & 783049 & PEЯPE 1 & 770172 & 7064 & \\
\hline
\end{tabular}


SHAMOKIN OPERATING COST SUMMARY

$\begin{array}{lrrrrrr}\text { LOAD FACT } & .925 & .925 & .925 & .925 & .925 & .925 \\ \text { AVAILABILITY } & 1.000 & 1.000 & 1.000 & 1.000 & 1.000 & 1.000 \\ \text { EFFICIENCY } & .735 & .735 & .735 & .735 & .735 & .735 \\ \text { Ca/S. } & 2.500 & 2.500 & 2.500 & 2.500 & 2.500 & 2.500 \\ \text { CULM COST } & 2.000 & 2.000 & 2.000 & 2.000 & 2.000 & 2.000 \\ \text { ASH DISP } & 2.000 & 2.000 & 2.000 & 2.000 & 2.000 & 2.000 \\ \text { LIMESTONE } & 5.500 & 5.500 & 5.500 & 5.500 & 5.500 & 5.500 \\ \text { POWER FACTOR } & .750 & .500 & .250 & 0.000 & 1.000 & 1.000 \\ \text { LABOR FACTOR } & 1.000 & 1.000 & 1.000 & 1.000 & .750 & .500 \\ & & & & & & \\ \text { SPF } & .925 & .925 & .925 & .925 & .925 & .925 \\ \text { STM PROD } & 18500 & 18500 & 18500 & 18500 & 18500 & 18500 \\ \text { CULM IN } & 7294 & 7294 & 7294 & 7294 & 7294 & 7294 \\ \text { STONE IN } & 732 & 732 & 732 & 732 & 732 & 732 \\ \text { ASH OUT } & 5618 & 5618 & 5618 & 5618 & 5618 & 5618 \\ \text { FIXED COST } & 29.06 & 29.06 & 29.06 & 29.06 & 22.85 & 16.65 \\ \text { CULM COST } & 7.29 & 7.29 & 7.29 & 7.29 & 7.29 & 7.29 \\ \text { STONE COST } & 2.01 & 2.01 & 2.01 & 2.01 & 2.01 & 2.01 \\ \text { DISP COST } & 5.62 & 5.62 & 5.62 & 5.62 & 5.62 & 5.62 \\ \text { VARBL COST } & 32.40 & 25.01 & 17.62 & 10.24 & 39.79 & 39.79 \\ \text { S/HR } & & & & & & \\ \text { \$/1000 } & 76.39 & 69.00 & 61.61 & 54.22 & 77.57 & 71.36 \\ \text { \$/YR } & 4.13 & 3.73 & 3.33 & 2.93 & 4.19 & 3.86 \\ & 669,000 & 604,000 & 540,000 & 475,000 & 680,000 & 625,000\end{array}$


APPENDIX C-2

SHAMOKIN OPERATING COST SUMMARY GROSS SALES OPTION 
SHAMOKIH DFERATIHI OOST SUMMARY

GROSS BALE DFTIDN

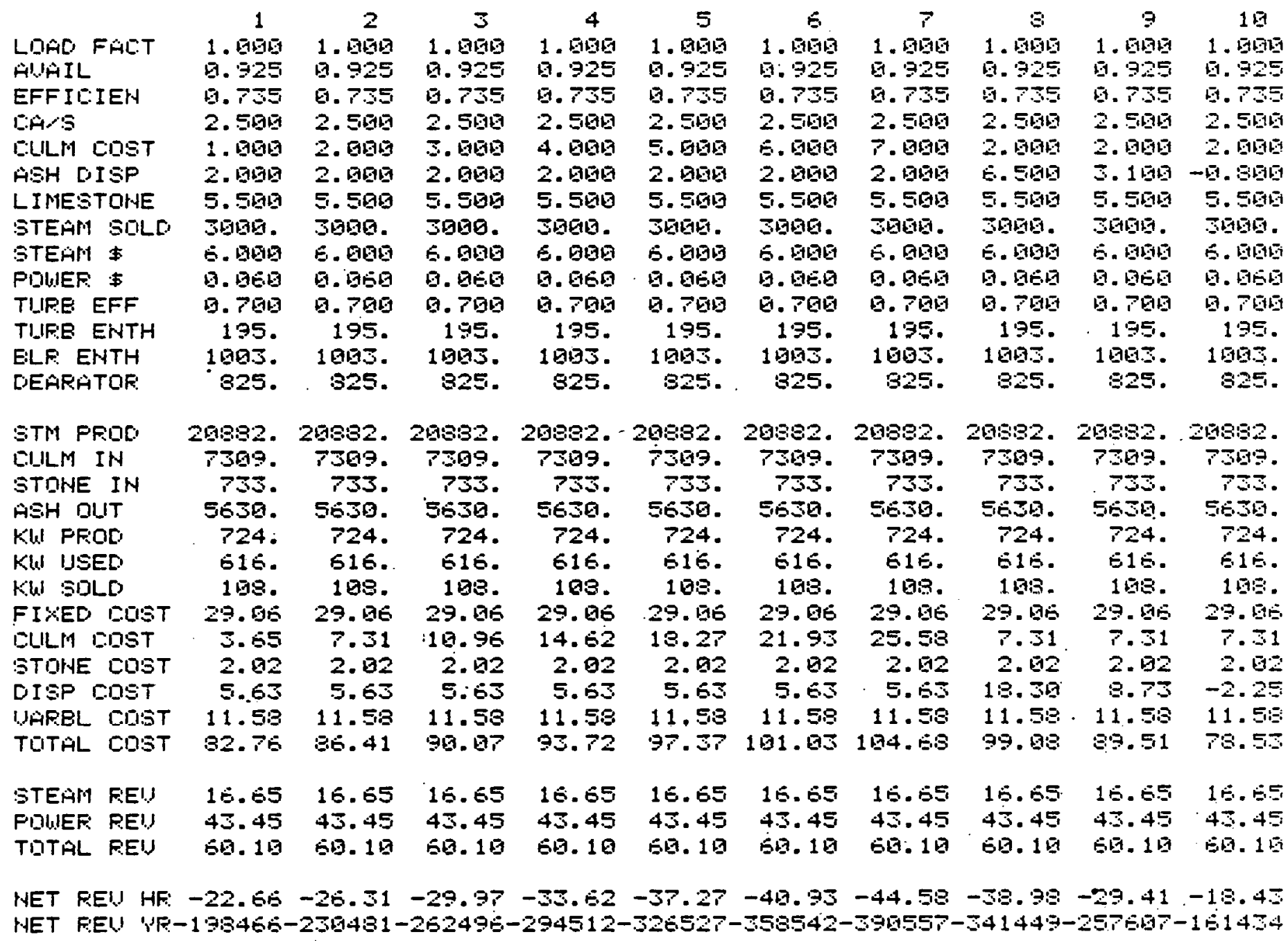




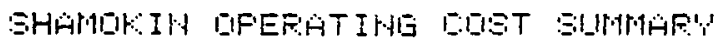

BFUSS SALE DFTIOHA

\begin{tabular}{|c|c|c|c|c|c|c|c|c|c|c|}
\hline & 11 & 12 & 13 & 14 & 15 & $1 E$ & 17 & 19 & 19 & $2 \sqrt{1}$ \\
\hline GAD FAET & 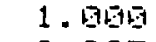 & 1. E10 & 1. E160 & 1.0019 & 1. 51015 & 1. 0010 & 1. & 1.0810 & 1. 915 & 1.8015 \\
\hline IAIL & 0.925 & 5.925 & 1.925 & 0.925 & 19.925 & 0.925 & 19.95 & 6.9 & 0.925 & 可. \\
\hline EFFIEIEH & 9.735 & 9.735 & 0.735 & 0.785 & 6.755 & 9.75 & Q. 7.5 & ‥7. 75 & E. 75 & ㅇ. 735 \\
\hline EA: & 2.506 & 2.5619 & 2.5609 & 2.506 & 2.506 & 2.569 & 2.5619 & 2.5016 & 2.5010 & 2.5090 \\
\hline BULM EDET & 2.500 & 2.0186 & 2.0101 & 2.0130 & 2. 01010 & 2. 01015 & 2. 615 & 2.0100 & 2.6010 & \\
\hline SH DISF & 2.01810 & 2.0190 & 2.01919 & 2. 61615 & 2. 01519 & 2.5015 & 2. 01010 & 2.0100 & 2.915 & \\
\hline IMESTOHE & 5.5010 & 5.500 & 5.560 & 5.500 & 5.560 & 5.501 & 5.5019 & 5.5015 & 5.560 & \\
\hline STEAM SDLD & 45616. & 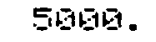 & 560616. & PEEt & : & 961日E. & BDisen. & SElete. & S1610. & 5010 \\
\hline STEAH & E. B日19 & E. B. & E. 0001 & E. 6150 & E. E010 & B. E010 & 4. 01916 & B. E1 & 1日. B日E & E. G010 \\
\hline F'UUIEF: & 日. 856 & 日. 80 & 6. 50 & 旬. & E. Bris & a. 576 & 6.56 & 5.805 & $9 \cdot 8$ & 百. \\
\hline TILEE EFF & 19.7日日 & Q.7019 & & 6. PED & 日. 7 . & 0.706 & 9.700 & 6.790 & 9.750 & 日.7 \\
\hline TLIFE ENTH & 195. & 195 & 195. & 195. & 195. & 195 & 195. & 195. & $15 \overline{0}$. & 195 \\
\hline E:LF EHTH. & 1010.5. & 1903. & 1919. & 1915. & 19日3. & 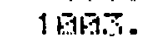 & 1607. & 1005 & 160. & 1002. \\
\hline EAF:ATTOP & 325 & 325 & 325 & 825. & 825 & 825 & 825 & 325 & 825. & 35 \\
\hline STM FFIOE & 201302 & 201382. & 2010:32. & 20082 & $2013: 32$ & 201813: & $201: 00$ & 200132. & 2耳1:日2: & 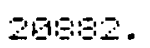 \\
\hline EIULM IH & 75199 & P.SE9. & $P S 69$. & 75日9. & 7569 & 7369. & 7509 & 7369 & 7309 & 7369 \\
\hline STENE IH & 733 & 733 & 735 & 735 & 733 & 73 & 73. & $\overrightarrow{30 .}$ & 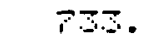 & $P 3$. \\
\hline ASH BUT & 5530. & 536. & 5658 & 5638. & $56 \Omega$ & 5030. & 5630 & 50.80. & 50.5. & 585. \\
\hline Flu FFOC & $8: 37$. & 5.58. & 613 & 578. & 530. & 502 & 724 & 724 & 724 & \\
\hline KIN IISEED & 616. & 516. & 516. & E15. & $51 E$. & $\therefore 16$. & 515. & Б16. & 615. & 5 \\
\hline $1 \sin 0$ & P1. & 34. & -3 & -4 트. & $-7 \%$ & -114 & 109. & 1018 & $10:$ & $1 E$ \\
\hline L KED EDST & 29.98 & 29.195 & 29.06 & 29.16 & 29.15 & 29.06 & 29.96 & 29.66 & $2 \% .56$ & 29.65 \\
\hline EULA EOSET & 7.31 & 7.31 & 7.31 & 7.31 & 7.31 & $? .31$ & 7.31 & 7.31 & 7.51 & \\
\hline STOHE CIOST & 2.62 & 2.82 & 2.02 & 2.02 & 2.152 & 2.02 & 2.02 & 2.62 & 2.62 & \\
\hline IEF OIET & 5.6 .3 & 5.63 & 5.83 & 5.63 & 5.65 & 5.65 & 5.83 & 5.53 & 5.5 & \\
\hline AFEL L:IST & 11.56 & 11.518 & 11.58 & 11.58 & 11.50 & 11.59 & 11.56 & 11.58 & $11.5: 5$ & 11. \\
\hline DTAL D:ID:TT & 65.41 & 85.41 & 86.41 & 30.41 & $B .41$ & $5: .41$ & S6. 41 & 88.41 & $5=.41$ & \\
\hline :TEAAM FEY & 22.26 & 27.75 & 50.51 & 38 & 44 & 95 & 10 & 22.20 & 27.75 & $1:$ \\
\hline FIDIUEF FEIU & 41.23 & 59.61 & 86.7 & 34.57 & 32.55 & 50.13 & 45.45 & 43.45 & 45.45 & \\
\hline DTAL FEU & 63.43 & $E S$. & 79.60 & 75.42 & அே・・早 & $B \cdot .9 B$ & 54,55 & 65.65 & 71.25 & \\
\hline ET FEU ! & 3 & & & $\therefore$ & & -8. & $=1$. & 20.76 & -1.5. & \\
\hline-7.78 & & & & & & & & & & \\
\hline
\end{tabular}




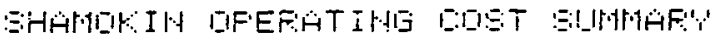

GFUES SHLE IFTIDAt

\begin{tabular}{|c|c|c|c|c|c|c|c|c|c|c|}
\hline & 21 & 22 & 25 & 24 & 25 & 28 & 27 & 20 & 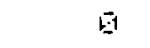 & \\
\hline TAO FAOT & 1. 1010 & 1. 01510 & 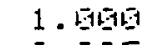 & 1. 5100 & 1. DES & 1. E1E & 1. E150 & 1. Elat & 59.81010 & 토을 \\
\hline & 0.925 & 0.925 & 9.525 & 6.925 & 9. 9 & 0.925 & 9.925 & 1. Etsta & ‥ EN & A10 \\
\hline EFFII:IEH & 9.75 & 0.795 & 6.75 & ‥7.9. & 8.735 & 9.785 & Q.7.7.5 & 9.75 & E. E619 & 5. 50150 \\
\hline ZA & 2.54017 & 2.51010 & 2.560 & 2.5010 & 2.515151 & 2.560 & 2. 5615 & 2.5101 & 6. E419 & 9010 \\
\hline HILM EOIST & 2.619 & 2.61609 & 2 . Bive & 2. 0196 & 2.010 & 2. E150 & 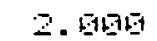 & 2 DEDG & 可. E150 & Q. 9019 \\
\hline$E H$ DISF & 2. B1E19 & 2.01515 & 2.01015 & 2.01019 & 2.8150 & 2.61016 & 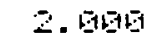 & 2.61516 & 6. 6019 & E. Genta \\
\hline IME STOTHE & 5. 56트 & 5.565 & 5.565 & 5.510 & 5.5010 & 5.5150 & 5.5019 & 5.5 & 9. 0100 & Q. 6010 \\
\hline TEAN SOLO & SEEDE. & 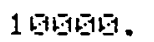 & 1101010. & 120101. & 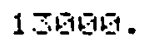 & 1401619. & 15601. & 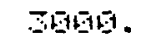 & 5. & 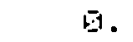 \\
\hline TEAM & S. BEA & E. BE1E & E. ENE & E. 0160 & E. E1016 & 5.650 & S. E610 & E. E1E & Q9. & 0.8 \\
\hline Zn!lE: & 回. 940 & 可. 08 & 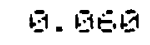 & 日. 010 & 8.90 & 日. 806 & 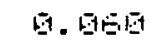 & 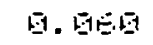 & Q9.015 & E. \\
\hline FE:E EFF & 田.7日日 & 6.7日6 & Q. PEQ & 9. 7009 & ․․ 750 & 6. 756 & 5.796 & 日. F回日 & 9. 5190 & . 601 \\
\hline IFEE EHATH & 195. & 195. & 195. & 135. & 19.5. & 195. & 195. & 195. & 回。 & . \\
\hline F: EFHTH & 1016. & 1 1015. & 100. & 1610. & 1 멍. & 1013. & 1 ENe. & 1016 & E. & . \\
\hline EARATQR: & 025 & 825. & 325 & 325. & 825 & В25. & 825 & $\exists 25$ & 1. & \\
\hline TA F'PECO & F1::1::2. & $210: 30$ & 215:32. & 2E1BE: & 20:5 & $2 \ln 82$. & 2019 & 2255 & 回。 & \\
\hline ILW IN & 7309 & 7ㄴ.69. & 7389. & 730 & 7509. & PSEO & 736 & 7962. & 果. & \\
\hline TOHAE IH & $P 3 E$. & $P B=$ & 73.5 & 733 & 75 & $P B S$. & 75. & P.5. & 日。 & \\
\hline SH DHTT & 5630. & 5630. & 5380. & $\sin 5$ & 503. & 58. & 可ESB. & EDEF & 日. & \\
\hline d FEOE & 724 & 455. & 428 & 91 & 54 & 317 & 201. & 78. & E. & \\
\hline to LISEE & $\theta 16$. & E1E. & E15. & B1E. & E1E. & S1s. & S1E. & 849. & 四。 & \\
\hline d SOLL & 1615 & -151 & $-1: 8$ & -225 & -282 & -299. & -30 & 154 & 里。 & \\
\hline INEO VOSTT & 29.65 & 29.65 & 29.61 & 20.0 & 29.61 & 29.61 & 29.50 & 29. & ㅌ.1日画 & E. \\
\hline ILM EOST & $7 . .1$ & 7.81 & 7.51 & 7.31 & P. $: 1$ & 7.31 & 7.31 & 7.96 & Q. E15 & \\
\hline TEHE GOEST & 2.02 & 2.82 & 2.62 & 32 & & 2.1 & 2. & 2.15 & 9. 80 & \\
\hline$I \subseteq F \quad$ LISTT & 5.63 & 5 & 5. & 5. & & 5.65 & 5.85 & 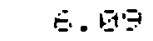 & E. 515 & \\
\hline HEELL ROET & 11.58 & $11.5: 3$ & 11.5 & 11. & 11. & 11.58 & 11.58 & 12.30 & 日. & 百。国 \\
\hline ETAL EIIST & EE.41 & BE. & 5.41 & 5.41 & : & 86.41 & $8=.41$ & 96.81 & 5.515 & 5.5 \\
\hline TEAM FEU & $1 E .65$ & 5 & 51 & & & 7 & 0 & $1:$ & 0.05 & \\
\hline EIUEF: F:EI!I & 28.97 & 27. & 2. & 23 & & 19.65 & $1 \Xi .51$ & 45.97 & 回. 16 & 5.5 \\
\hline GTAL_ FEU & 4.5 .62 & 83.41 & 58.74 & 901.57 & 95.48 & 96.75 & 1515. 5 & 84.97 & 1. 501 & 日. \\
\hline ET FE:EU HF & 69 & -5 & & & & 15 & 1. & -25.54 & B. 515 & 5.6 \\
\hline$\because F$ & & - & 20 & 56 & $E 1$ & & $11 \%$ & 5 & & \\
\hline
\end{tabular}


$\triangle$ APEENDIX D

DEFINITION OF TERMS 
Ash Disposal Cost: Cost of ash disposal (fly ash and bottom ash) including trucking cost in dollars per ton of ash.

Availability: Fraction of total time that the boiler can operate when downtime, both planned and unplanned, is subtracted. Historically for the nine month test program this has been 0.925 , which is used as the base case in all comparisons.

Boiler Efficiency: Enthalpy increase of the steam/water in the boiler divided by the higher heating value of the coal being fed per unit time. The design boiler efficiency of the Shamokin FBC is 0.735 .

Ca/S Ratio: Molar ratio of calcium in the limestone to sulfur in the fuel.

Culm Cost: Cost of anthracite culm delivered to the plant in dollars per ton.

Deaerator or Internal Steam use: The quantity of steam required to heat the boiler feedwater to approximately $220^{\circ} \mathrm{F}$ at which point dissolved gases in the water are released. For the design base case 3,400 pph of steam is used by the deaerator to heat $20,000 \mathrm{pph}$ of boiler feedwater from approximately $55^{\circ} \mathrm{F}$, since no steam condensate is returned to the system. For cogeneration cases wherein condensate is returned, this quantity would be reduced.

Enthalpy: In thermodynamic analysis, the combination $U$ + PV occurs so frequently that it has been given the name enthalpy.

Limestone Cost: Cost of limestone delivered to the plant in dollars per ton.

Load Factor: Fraction of full boiler flow being considered as maximum. For historical case this is 0.75 (i.e., 15,000 pph) which is the current continuous maximum steam production because of limits of baghouse capacity, etc. All other cases utilize a 1.00 load factor as the base case, i.e., 20,000 pph net steam flow or 23,400 pph gross steam flow. 
Power Price: Selling price of power generated by the plant in dollars per $\mathrm{kW}$ net or gross power production.

Steam Price: Selling price of steam generated by the plant in dollars per $1000 \mathrm{lb}$ of steam.

Steam Production Factor: Product of load factor and availability. The steam production factor multiplied by the boiler capacity yields a net steam flow available for sale or other usage.

Turbine-Enthalpy: Available enthalpy difference between inlet condition and condenser conditions for turbine power generation in Btu/lb steam.

Turbine Generator Efficiency: Fraction of the available enthalpy of steam, between entering conditions and condenser conditions, which is converted to electrical power. For industrial turbine generators in the size range useable at Shamokin, this efficiency is approximately 0.70 . 
